ÉGYPTE

monde arabe

\section{Égypte/Monde arabe}

$12-13 \mid 1993$

Une économie en transition

\title{
Bibliographie des thèses en sciences sociales concernant le secteur agricole et la société rurale en Égypte
}

Thèses soutenues en France, en Allemagne, en Grande-Bretagne et aux États-Unis

URL : https://journals.openedition.org/ema/1315

DOI : 10.4000/ema.1315

ISSN : 2090-7273

Éditeur

CEDEJ - Centre d'études et de documentation économiques juridiques et sociales

Édition imprimée

Date de publication : 31 mars 1993

Pagination : 489-542

ISSN : 1110-5097

Référence électronique

"Bibliographie des thèses en sciences sociales concernant le secteur agricole et la société rurale en Égypte », Égypte/Monde arabe [En ligne], 12-13| 1993, mis en ligne le 08 juillet 2008, consulté le 07

juillet 2022. URL : http://journals.openedition.org/ema/1315; DOI : https://doi.org/10.4000/ema.1315

Ce document a été généré automatiquement le 7 juillet 2022

Tous droits réservés 


\section{Bibliographie des thèses en sciences sociales concernant le secteur agricole et la société rurale en Égypte}

Thèses soutenues en France, en Allemagne, en Grande-Bretagne et aux

États-Unis

1 Prenant la suite des deux bibliographies sur l'agriculture et la société rurale égyptiennes parues dans les numéros 19 et 21 du Bulletin du CEDEJ ${ }^{1}$, celle que l'on présente ici répertorie les thèses concernant les mêmes thèmes et soutenues dans les universités des quatre pays occidentaux dont tout donne à croire qu'y est élaborée la plus grande part des travaux universitaires en sciences sociales portant sur l'Égypte contemporaine, à l'exception, bien sûr, de ce pays lui-même; il s'agit des États-Unis (USA), de la France (F), de l'Allemagne (D) (ex-RFA comme ex-RDA) et de la GrandeBretagne $(\mathrm{GB})^{2}$. Ces thèses sont donc rédigées en langues anglaise, française ou allemande ${ }^{3}$.

2 La liste thématique que l'on trouvera plus loin vise l'exhaustivité ; il ne s'agit donc pas là d'une bibliographie critique, que la seule difficulté matérielle d'accès aux thèses rendait par elle-même impossible, sans parler du temps de lecture nécessaire. Sur la base des listes annuelles et des répertoires rétrospectifs des thèses soutenues dans ces quatre pays ${ }^{4}$ et de bibliographies nationales des thèses concernant le monde arabe et musulman ${ }^{5}$ ont été sélectionnées l'ensemble de celles qui concernent l'Égypte ${ }^{6}$ et qui portent - d'après ce que peut laisser supposer leur titre - sur l'espace rural, le secteur économique agricole (production, commercialisation, distribution et consommation), les paysanneries, la population et la société rurales, le développement agricole ou rural, les industries agro-alimentaires et les problèmes nutritionnels et alimentaires (sécurité, autosuffisance et dépendance).

3 Ce principe de sélection a permis de retenir 339 thèses et mémoires soutenus entre 1889 et $1992^{7}$ soit 304 travaux de doctorat, répartis en 158 Ph.D. et 2 D.Sc. (USA et GB), 83 Dissertation (D), 61 thèses $(F ; 11$ thèses d'État es Lettres et Sciences Humaines ou 
Economie, 18 thèses de Droit, 22 thèses de troisième cycle, 2 thèses dites de " nouveau régime " et 8 de nature non spécifiée), et 35 travaux correspondant à des diplômes inférieurs au doctorat ( 25 thèses de master, 3 mémoires de bachelor, 7 mémoires de DEA ET DESS).

4 Pays et date de soutenance, origine des auteurs et thèmes de recherche

5 Les pays de soutenance sont représentés dans les proportions suivantes: Tableau 1 : pays de soutenance

Tableau 1 : pays de soutenance

\begin{tabular}{|c|c|c|}
\hline Pays & $\begin{array}{c}\text { nombre de thèses } \\
\text { soutenues }\end{array}$ & $\%$ \\
\hline USA & 104 & 30,7 \\
GB & 83 & 24,5 \\
D & 74 & 21,8 \\
F & 68 & 20,0 \\
O & 7 & 2,00 \\
S & 2 & 0,60 \\
C & 1 & 0,30 \\
\hline total & 339 & $100 \%$ \\
\hline
\end{tabular}

6 Ces proportions réservent peu de surprise, si ce n'est peut-être l'importance de la part des thèses soutenues en Allemagne (essentiellement en RFA, d'ailleurs, la RDA n'étant bien représentée que durant les années soixante et le début des années soixante-dix) ${ }^{8}$.

7 Chronologiquement, les années de soutenance se répartissent de la façon suivante :

Tableau 2 : années de soutenance

\begin{tabular}{|c|c|c|c|c|c|c|c|c|c|c|}
\hline & $\begin{array}{c}\text { av. } \\
1910\end{array}$ & $10-19$ & $20-29$ & $30-39$ & $40-49$ & $50-59$ & $60-69$ & $70-79$ & $80-89$ & $\begin{array}{c}\text { ap. } \\
1989\end{array}$ \\
\hline n. & 5 & 5 & 15 & 12 & 20 & 42 & 56 & 70 & 107 & 7 \\
i & 12 & 12 & 36 & 29 & 48 & 100 & 133 & 166 & 255 & - \\
\hline
\end{tabular}

$02: \mathrm{i}=$ indice base 100 en 1950-59

8 On constate plusieurs «bonds " (n'engageant, pour les deux premiers, que de faibles effectifs), le premier dans les années vingt, le second dans les années cinquante, et le troisième dans les années quatre-vingt. L'on verra que cette progression est très liée au rythme d'arrivée des "vagues » d'étudiants égyptiens venus faire leur thèse dans les différents pays pris en compte.

9 Cependant, à ne considérer que les années 1940-90 ( $\mathrm{n}=302$, soit $89 \%$ du total) et malgré les deux «accélérations » de rythme de soutenance que connaissent ces dernières, la progression est loin de suivre celle des effectifs de thèses soutenues - dans ces pays et pour la même période - en sciences sociales en général et sur le monde "arabo- 
musulman » en particulier. À titre d'exemple, les thèses de sciences sociales, littérature et islamologie soutenues aux États-Unis sur le Monde arabe et l'Islam passent de 1.825 titres pour la période 1883-1974 (92 ans et une moyenne de 20 thèses/an) à 2.142 titres pour la période 1981-87 ( 7 ans et une moyenne de 306 thèses/an) ${ }^{9}$, soit un effectif moyen de thèses/an multiplié par 15 , ce qui correspond d'assez près à la progression des effectifs de PhD soutenus en sciences sociales aux USA ; pour les mêmes périodes de référence, les effectifs de thèses soutenues sur l'Égypte rurale dans les pays retenus ici passent de 183 à 75, soit d'une moyenne de 2 thèses/an à 11 thèses/an et une multiplication par 5,5 seulement ${ }^{10}$. En admettant que l'on assiste en GB, D et $F$ à une progression semblable à celle repérée aux USA des effectifs de doctorats portant sur le Monde arabe ${ }^{11}$, l'on peut conclure à un reflux relatif, dans ces quatre pays, des études agraires et rurales en sciences sociales portant sur l'Égypte (les effectifs de ruralistes augmentant moins vite que ceux des autres spécialités).

L'explication la plus probable en est qu'une proportion croissante des effectifs d'étudiants égyptiens venant faire leur doctorat dans ces pays choisissent d'autres thèmes de recherche (ceci compte tenu du fait très général que les doctorats soutenus dans un pays « développé » et portant sur un pays donné du Tiers Monde sont dans leur très grande majorité l'oeuvre d'étudiants originaires de ce dernier pays). Cependant, avant de ramener ce reflux relatif à celui plus général des études rurales portant sur les pays du Tiers Monde, ce sont aussi aux effectifs de thèses en sciences sociales portant sur l'Égypte soutenues dans ces quatre pays qu'il faudrait pouvoir comparer ces données; la part relative des travaux portant sur ce pays dans l'ensemble de ceux qui concernent le Monde arabe semble en effet diminuer, ce qui va de pair avec la baisse de proportion, dans l'ensemble des étudiants arabes "migrants", des étudiants égyptiens venus faire un $\mathrm{PhD}$ à l'étranger, phénomène lui-même lié à l'augmentation des étudiants originaires d'autres pays arabes (de la Péninsule arabique et du Soudan, en particulier, pour ce qui concerne les USA). Les deux tendances générales évoquées ici (reflux relatif des études rurales «tiers mondistes » et diminution relative des effectifs d'étudiants égyptiens au sein de ceux des étudiants « migrants » arabes) se conjuguent très probablement pour expliquer le phénomène mis en relief, mais n'en rendent peutêtre pas entièrement compte ; outre la possibilité d'une plus forte désaffection, de la part d'étudiants égyptiens "migrants " issus de nouvelles couches sociales aisées, à l'égard d'études portant sur un secteur particulièrement dévalorisé depuis l'infitah, il faudrait mesurer la tendance qu'ont les doctorants en sciences sociales venus de pays du Tiers Monde à «appliquer » moins souvent leur problématique à leur propre pays d'origine.

11 Si l'on dispose de peu d'information sur ce sujet, par contre, un relevé des noms des auteurs de thèses permet de se faire une idée de leur origine nationale ${ }^{12}$. Celle-ci se distribue de la façon suivante : 
Tableau 3 : origine des docteurs

\begin{tabular}{|l|c|c|}
\hline \multicolumn{1}{|c|}{ Origine } & nombre & $\%$ \\
\hline Egyptienne & 252 & 74,30 \\
Américaine (US) & 35 & 10,30 \\
Allemande & 24 & 7,10 \\
Française & 19 & 5,60 \\
Anglaise & 9 & 2,70 \\
\hline Total & 339 & 100,00 \\
\hline
\end{tabular}

$03:{ }^{*}+$ autrichienne et suisse

12 Les trois-quarts des auteurs de thèses portant sur l'agriculture et la société rurale égyptiennes sont donc eux-mêmes égyptiens, ce qui reflète la tendance générale énoncée plus haut. Une surprise (qui n'en est en fait pas une) apportée par la lecture de ce tableau réside dans la constatation de la très faible proportion d'auteurs anglais (mais il y a parmi eux R. Owen et H. Rivlin !), ce qui ne reflète guère l'intérêt politicoéconomique "pratique» que la Grande-Bretagne porta à l'Égypte mais confirme l'impression d'un faible investissement en vue de sa connaissance scientifique; en témoigne par exemple, pour la période d'avant la Révolution de 1952, la faible proportion d'anglais parmi les membres des sociétés savantes égyptiennes, pourtant si «étrangères» à l'époque par leur recrutement (Institut d'Égypte, Société de Géographie, Société khédiviale d'Economie politique, de Statistique et de Législation). La nombre d'auteurs américains (USA) traduit par contre assez bien l'intérêt porté par ce pays, depuis le milieu des années soixante-dix, à certains aspects de l'agriculture égyptienne (« sécurité » alimentaire, productivité, déréglementation, etc.).

Enfin, l'on a tenté de classer les thèses en six rubriques croisant disciplines et grands thèmes de recherche ( 1 : histoire économique et/ou sociale de l'agriculture et de la paysannerie ; 2 : géographie rurale régionale ; 3 : économie de la production agricole ; 4 : économie des échanges et de la consommation de produits agricoles, nutrition, alimentation et sécurité alimentaire; 5: sociologie et anthropologie de la société rurale; 6: études sur le développement et la planification agricoles), en affectant souvent un peu artificiellement chaque thèse à une seule de ces rubriques, ce qui donne la ventilation suivante :

Tableau 4 : thèmes et disciplines

\begin{tabular}{|c|c|c|c|c|c|c|c|}
\hline Sujet & 1 & 2 & 3 & 4 & 5 & 6 & tolal \\
\hline & & & & & & & \\
$\%$ & 20 & 23 & 117 & 58 & 75 & 46 & 339 \\
& 5.9 & 6.8 & 34,5 & 17,1 & 22,1 & 13,6 & $100 \%$ \\
\hline
\end{tabular}

Comme on peut le constater, les recherches d'économie agricole constituent à elles seules les deux tiers des effectifs des thèses, le tiers restant se partageant inégalement entre les approches historiques, géographiques, sociologiques et anthropologiques. 


\section{Quelques corrélations et tendances}

Il était tentant de croiser entre eux les quatre indicateurs retenus (date de soutenance, origine nationale des auteurs, pays de soutenance et thème/discipline) ${ }^{13}$. En ce qui concerne la répartition chronologique des thèses selon le pays de soutenance (cf. tableau 5), la France vient largement en tête avant 1940 (19 thèses sur 37, aucune thèse n'étant soutenue aux USA) et verra ses effectifs chuter lors des deux périodes suivantes, durant lesquelles les thèses passées en GB et aux USA dominent largement (1940-1969). La dernière période (1980-92) voit les effectifs à leur maximum dans chaque pays - à l'exception notoire de la $\mathrm{GB}-42 \%$ des thèses étant des $\mathrm{PhD}$ américains. En fait, seule l'Allemagne connaît une croissance quasi régulière tout au long du siècle, une cinquantaine de thèses (sur 83) y étant soutenues de 1970 à 1990.

Tableau 5 : répartition des thèses par pays de soutenance

\begin{tabular}{|c|c|c|c|c|c|}
\hline & F & GB & D & USA & 1otal \\
\hline av. 1940 & 19 & 9 & 9 & 0 & 37 \\
$1940-59$ & 6 & 24 & 6 & 26 & 62 \\
$1960-69$ & 1 & 14 & 17 & 24 & 56 \\
$1970-79$ & 15 & 23 & 25 & 7 & 70 \\
$1980-92$ & 27 & 13 & 26 & 48 & 114 \\
\hline total & 68 & 83 & 83 & 105 & 339 \\
\hline
\end{tabular}

Quelle que soit la période prise en compte, les étudiants égyptiens constituent toujours l'essentiel des titulaires de thèses (cf. tableau 6) : ils représentent $68 \%$ de leurs effectifs avant $1940,83,5 \%$ entre cette dernière date et 1980 , pour retomber à $61 \%$ durant la dernière décennie, ceci bien que leur nombre absolu aille croissant; durant cette dernière période, les étudiants américains, quasi absents auparavant du champs des études rurales sur l'Égypte, se taillent une place non négligeable (un quart des 114 thèses soutenues) ; les Français n'apportent une contribution significative à ces études qu'après 1970 ( 15 thèses sur les 19 qui sont l'œuvre d'étudiants ressortissants de ce pays) ; les étudiants allemands se maintiennent, à un niveau modeste, tout au long du siècle et leurs homologues anglais disparaissent pratiquement du champ - qu'ils ont toujours très peu occupé - dans les années soixante.

Tableau 6 : répartition des titulaires de thèses par date et par pays

\begin{tabular}{|c|c|c|c|c|c|c|}
\hline & Egypte & D & F & GB & USA & lolal \\
\hline av. 1940 & 25 & 6 & 3 & 3 & 0 & 37 \\
$1940-59$ & 53 & 4 & 1 & 3 & 1 & 62 \\
$1960-69$ & 42 & 7 & 0 & 1 & 6 & 56 \\
$1970-79$ & 62 & 2 & 6 & 0 & 0 & 70 \\
$1980-92$ & 70 & 5 & 9 & 2 & 28 & 114 \\
\hline lotal & 252 & 24 & 19 & 9 & 35 & 329 \\
\hline
\end{tabular}



des 83 thèses soutenues sur l'agriculture et la société rurale égyptienne en GrandeBretagne, des sept dixièmes des 83 et 68 thèses soutenues respectivement en Allemagne et en France et des deux tiers de celles (au nombre de 105) qui ont été passées aux USA.

S'agissant des thèmes/disciplines (cf. tableau 7), l'économie de la production agricole occupe, quelle que soit la période, la première place (elle représente les trois-quarts des thèses avant 1940, et entre le quart et le tiers durant les périodes suivantes, avec des effectifs relativement stables). La géographie régionale connaît son apogée entre 1940 et 1960, les études sur le développement et la planification agricole durant les années 1960-80 et l'analyse économique des échanges et de la consommation agricoles après 1980. Quant aux recherches d'histoire économique et sociale et à la socio-anthropologie rurale, leur nombre progresse régulièrement, les premières en restant à un niveau fort modeste tout au long du siècle, mais les secondes en rejoignant dans les années quatrevingt les effectifs (32) des travaux portant sur l'économie de la production. Un certain "économisme" (un «macro-économisme», pourrait-on dire, et même un " économétricisme ») coexiste donc maintenant avec un développement des recherches de terrain qui, sans négliger une indispensable - et encore bien embryonnaire anthropologie économique des paysanneries, commencent à explorer des aspects quasi inconnus de la société rurale égyptienne (alimentation, hygiène, santé, représentations du corps et de la maladie, sexualité, fécondité, «gender » etc., et ceci souvent sous la pression de la nécessité de plus en plus ressentie par diverses instances d'en savoir plus pour agir à meilleur escient).

Tableau 7 : répartition des thèmes par dates

\begin{tabular}{|l|c|c|c|c|c|c|c|}
\hline dales thèmes & 2 & 1 & 6 & 4 & 5 & 3 & total \\
\hline av. 1940 & 3 & 0 & 0 & 2 & 4 & 28 & 37 \\
$1940-59$ & 9 & 3 & 4 & 13 & 12 & 21 & 62 \\
$1960-69$ & 3 & 4 & 13 & 8 & 13 & 15 & 56 \\
$1970-79$ & 3 & 5 & 18 & 9 & 14 & 21 & 70 \\
$1980-92$ & 5 & 8 & 11 & 26 & 32 & 32 & 114 \\
\hline total & 23 & 20 & 46 & 58 & 75 & 117 & 329 \\
\hline
\end{tabular}

19 L'analyse de la production agricole domine également l'ensemble des thèmes répertoriés dans trois pays de soutenance sur quatre $(\mathrm{F}, \mathrm{GB}, \mathrm{D}$ où la proportion des thèses portant sur ce thème atteint pratiquement la moitié) (cf. tableau 8); ce n'est qu'aux USA que les thèses traitant de ce thème sont distancées par celles qui relèvent de la socio-anthropologie rurale (représentant plus du tiers des thèses soutenues dans ce pays sur l'agriculture et la société rurale égyptiennes et la moitié de celles soutenues dans ces disciplines dans l'ensemble des pays pris en compte ici). C'est donc principalement aux USA que sont impulsés les travaux anthropologiques évoqués à l'instant - dont les préoccupations «appliquées» ne sont pas absentes (recherches anthropologiques sur les déterminants de la fécondité en particulier). La prééminence, évoquée à l'instant, de l'Allemagne dans les travaux d'économie de la production agricole se double de celle des thèses portant sur le développement et la planification agraires (18 thèses sur les 46 portant en tout sur ces sujets, représentant près du quart des travaux allemands et soutenues pour la majorité en ex-RDA). Les préoccupations 
américaines en matière de commerce international agricole et plus particulièrement alimentaire, ainsi que les problèmes posés à (et par) l'Égypte en matière de " sécurité " dans ce dernier domaine, se retrouvent dans la place qu'occupent aux USA les travaux portant sur ces thèmes (dont il faut cependant remarquer que la représentation $(20 \%)$ dans l'ensemble des thèses soutenues dans ce pays n'est guère plus élevée que celle des mêmes thèmes au sein des travaux élaborés en Allemagne et en Grande-Bretagne (18\%). Enfin, la France se réserve le premier rang dans le domaine des études d'histoire rurale égyptienne (la moitié de la production totale) et la Grande-Bretagne dans celui des études de géographie régionale (parmi lesquelles on trouve la thèse du " géant » de la géographie égyptienne, Gamal Hamdan).

Tableau 8 : répartition des thèmes par pays

\begin{tabular}{|l|c|c|c|c|c|c|c|}
\hline pays & 1 & 2 & 6 & 3 & 4 & 5 & tot \\
\hline F & 9 & 4 & 5 & 26 & 8 & 16 & 68 \\
GB & 6 & 14 & 7 & 25 & 15 & 16 & 83 \\
D & 3 & 3 & 18 & 39 & 14 & 6 & 105 \\
USA & 2 & 2 & 16 & 27 & 21 & 37 & 83 \\
\hline total & 20 & 23 & 46 & 117 & 58 & 75 & 339 \\
\hline
\end{tabular}

Si, d'une part, la diagonale du tableau 8 semble présenter une assez belle " corrélation » entre prédominance de thèmes et pays de soutenance et si, d'autre part, les thèmes de recherche sont en partie liés aux préoccupations plus générales de leur période d'élaboration (cf. tableau 7, planification et développement dans les années soixante et soixante-dix par exemple), la très forte prépondérance des étudiants d'origine égyptienne rend très difficile l'analyse d'éventuelles corrélations entre origine nationale et thématique globale de recherche ${ }^{14}$.

21 Il ne peut être ici question d'entrer davantage dans le détail, pourtant fort révélateur, du poids relatif et de la diversité des thèmes de recherche explorés, de la très forte redondance de certains travaux (ou du moins de ce que leurs titres en laissent deviner), des lacunes, également, non moins "criantes"; une étude sérieuse sur ces points, permettant un réel «état de la recherche» sur l'Égypte rurale et son agriculture, supposerait une lecture attentive de l'ensemble de ces travaux - dont cette bibliographie non critique ne constitue qu'une condition préalable, celle de leur « repérage » - tâche qui relève d'un travail d'équipe et dont la réalisation matérielle supposerait d'abord un accès point trop malaisé aux thèses elles-méme. Bien sûr, un certain nombre de ces dernières ont fait l'objet, après une réécriture plus ou moins importante $e^{15}$, de publication sous forme de livre ${ }^{16}$; d'après un calcul succinct qui n'exclut pas l'inexactitude (en particulier par connaissance trop lacunaire des thèses allemandes qui ont pu être éditées), leur proportion ne devrait pas excéder $10 \%^{17}$ (encore s'agit-il souvent, en Allemagne en particulier, d'édition dans des collections très spécialisées dépendant d'une université). Il est assez remarquable par ailleurs que ce soit en majorité des thèses élaborées par des étudiants ressortissant du pays de 
soutenance qui sont publiées (alors que ces derniers, on l'a vu, ne représentent que le quart des effectifs de titulaires de thèse dans le domaine qui nous intéresse).

Il faut cependant rappeler pour conclure, d'une part, qu'ont seulement été examinées les thèses soutenues dans les quatre pays occidentaux dont on a fait l'hypothèse qu'ils regroupent le plus grand nombre de travaux élaborés sur l'Égypte hors d'Égypte (il faudrait donc aussi explorer le domaine des ex-pays de l'Est - dont seule la RDA est représentée ici - et celui des autres pays européens, en particulier riverains de la Méditerranée) et d'autre part, que c'est bien sûr en Égypte même et en langue arabe (mais pas exclusivement) que les thèmes qui nous intéressent ont fait l'objet du plus grand nombre de travaux universitaires (magisters ou doctorats) ${ }^{18}$.

Les 339 titres répertoriés ont été regroupés sous des rubriques hiérarchisées relativement détaillées dont on trouvera ci-dessous la liste et la pagination, une thèse pouvant prendre place sous plusieurs rubriques (les 339 titres font ainsi l'objet de plus de 500 occurrences). $\mathrm{Vu}$ le type de présentation adoptée et la taille modeste de cette bibliographie, l'on n'a pas jugé bon d'y joindre un index des auteurs.

\section{Histoire rurale}

\subsection{Période byzantine et arabe « classique " $\left(\mathrm{VIl}^{\mathrm{e}}-\mathrm{XV} \mathrm{e}^{\mathrm{e}}\right.$ siècle $)$}

WEHEBA A.F.M.M., The agriculture of Egypt during the Arab period (642-1517). M.A./ Univ. College/ London/ G.B./1952.

MULLER-WODARG D., Die Landwirtschaft Âgyptens in der frûhen 'Abbâsidenzeit en Égypte 750-969 n. Chr/132-358 d.H. (L'agriculture de l'Égypte durant la période abbasside, 750-969 après J.C/132-358 de l'Hégire). Dissert./ Hambourg UnivV Hamburg/ D./1953.

GASCOU J., La possession du sol, la cité et l'État à l'époque protobyzantine et particulièrement en Égypte. Recherches sur l'histoire des structures agraires, de la fiscalité et des institutions aux Ve,Vle,Vlle siècles Th. 3ème C. CI Univ. de Paris 1/Paris/F./1975.

ELFAKIR A., Disettes et famines en Égypte aux XIVe et XVe siècles. Th. 3ème CI Univ. de Toulouse II/ Toulouse/ F./1983.

BAKFALOUNI T., Les effets démographiques des épidémies, des guerres et des disettes au Proche-Orient du VIle au XIXe siècle. Th. 3ème C./ EHESS/ Paris/ F./1984.

\subsection{Période ottomane ( $\mathrm{xVl} \mathrm{l}^{\mathrm{e}} \mathrm{xVIII} \mathrm{e}^{\mathrm{e}}$ siècle $)$}

AL SINGABI T., L'Égypte à la fin du XVIIIe, les modes de production, la formation sociale et leur crise. DESS Sc. éco./ Univ. de Montpellier/ Montpellier/ F./1976.

BAKFALOUNI T., Les effets démographiques des épidémies, des guerres et des disettes au Proche-Orient du VIIe au XIXe siècle. Th. 3ème C./ EHESS/ Paris/F./1984.

31 CUNO K.M., Landholding, society and economy in rural Egypt, 1740-1850: a case study of Al Daqhaliyya Province. Ph.D./ Univ. of California/ Los Angeles, CA./ U.S.A./1985. 


\section{3. $\mathrm{XIX}^{\mathrm{e}}$ siècle}

32

\section{d'interprett
F./1983} F./1889. Manchester/G.B./1948. Oxford/ G.B./1954. D./1967. F./1977. DEA/ IEDES/ Paris/ F./1980. en-Provence/ F./1981.

GALI K., Essai sur l'agriculture de l'Égypte. Th. de l'Institut agricole de Beauvais/ Beauvais/

THOMAS G.H., Changing values in egyptian agriculture from 1800 to the present time. M.A./ Birkbeck College/ London/ G.B./1939.

SADEK D.A., The historical geography of Giza province. M.A./ Manchester Univ./

RIVLIN H.A., The agricultural policy of Muhammad 'Ali in Egypt. Ph.D./ Oxford Univ./

OWEN E.R.J., Cotton production and the development of the economy in 19th. century Egypt (1821-1914). Ph.D./ Oxford Univ./ Oxford/ G.B./1966.

SIMONS P., Die Entwicklung des Anbaus sowie die Verbreitung und Bedeutung der Nutzpflanzen in der Kulturlandschaft der âgypt. Nilstromoase von 1800 bis zur Gegenwart, eine agargeographische Untersuchung (Le développement de la culture, l'élargissement et la signification des plantes utiles dans le paysage cultural de l'oasis fluviale nilotique égyptienne de 1800 à nos jours ; une rech. de géo. agraire). Dissert./ Köln Univ./ Kôln/

ATTIA M., L'Égypte, ressources et population vues à travers les rapports de productions au cours de la première moitié du XIXe siècle. DESS Sc.éco/ Univ. de Montpellier/ Montpellier/

RUF T., L'agriculture égyptienne; essai d'analyse du développement depuis la fin du XVIIIe.

ALLEAUME G., Les provinces de Giza et de Beni Suef dans les « Khitat » de 'Ali Pacha Mubarak: introduction, traduction et essai d'interprétation. Th. 3ème C./ Univ. d'Aix-Marseille 1/Aix-

ATTIA M., L'Égypte, ressources et population à travers ses rapports de production de la deuxième moitié du XIXe siècle à la première guerre mondiale. Th. 3ème $\mathrm{Cl}$ Univ. de Montpellier 1/ Montpellier/ F./1981.

TUCKER J.E., Women and the family in Egypt, 1800-1860: a study in changing roles and status. Ph.D./ Harvard Univ./ Cambridge, MA./ U.S.A./1981.

YACCOB A.R.B., The evolution of land tenure and the agrarian economy in 19th. And early 20 th. century Egypt. M.Litt./ St Andrews Univ./ St Andrews/ Scotland, G.B./1982.

MOSTAFA Y., La formation historique de la dépendance de l'Égypte (1820-1930); essai RUF T., La formation agraire égyptienne de la fin du XVIIIe siècle à nos jours : analyse du fonctionnement des exploitations dans le nord du Delta et en Moyenne-Égypte. Th. 3ème C./ Univ. de Paris 1/ Paris/ F./1983.

CUNO K.M., Landholding, society and economy in rural Egypt, 1740-1850: a case study of Al Daqhaliyya Province. Ph.D./ Univ. of California/ Los Angeles, CA./ U.S.A./1985. 


\section{4. $x x^{\mathrm{e}}$ siècle}

GIRARD H., Présent et avenir agricole de la Basse-Égypte; un domaine dans le Delta. Thèse/ Inst. Agricole de Beauvais/ Beauvais/ F./1901.

EBERLI H... Die Veränderungen im Anbau der âgypt. Nahrungspflanzen, darg. im Zusammenhang mit der Zunahme der âgypt. Bevölkerung, dem Wandel im Ägypt. Bewässerungssystem und in der Landwirtshaft seit Ende des 19.J. (Les transformations de l'agriculture vivrière égyptienne et leur rapport avec l'accroissement de la population et le changement du système d'irrigation et d'agriculture depuis la fin du XIXe siècle). Dissert./ Zurich Univ./ Zurich/ S./ 1939.

SELIM H.K., Post war changes in the agricultural geography of Egypt. M.A./ Liverpool Univ./ Liverpool/ G.B./1939.

AMIN G.al-D.A., The food problem and economic development in Egypt since 1935. Ph.D./ London School of Economics/ London/ G.B./1962.

SHAFIK M., Der Zustand der ägyptischen Landwirtschaft vor und nach der Revolution von 1952 unter bes. Berücksichtigung der Stellung der Fellachen (La situation de l'agriculture égyptienne avant et après la Révolution de 1952, envisagée en particulier du point de vue de la position des fellahs). Dissert./ Graz Univ./ Graz/Ö./1963.

SCHITA A.R.M., Die Ânderung der Agrarstruktur in Âgypten in den letzten 50 Jahren (Le changement de la stucture agraire en Égypte dans les 50 dernières années). Dissert./ Graz Univ./ Graz/ Ô./1965..

EMBABI F.M.S., Population changes in the Nile Delta, 1927-1960. M.Litt./ Bristol Univ./ Bristol/G.B./1968.

KAZZIHA W.,The evolution of the political elite (1907-1921): a case study of the role of the large landowners in politic. Ph.D./ S.O.A.S./ London/ G.B./1971.

MOSTAFA Y., La formation historique de la dépendance de l'Égypte (1820-1930); essai d'interprétation à partir du surplus agricole. Th. État/ Univ. De Montpellier 1/ Montpellier/ F./1983.

56 RUF T., La formation agraire égyptienne de la fin du XVIIIe siècle à nos jours: analyse du fonctionnement des exploitations dans le nord du Delta et en Moyenne-Égypte. Th. 3ème C./ Univ. de Paris l/ Paris/ F./1983.

\section{2. géographie rurale et études à cadre régional}

\subsection{Delta (Basse-Égypte)}

57 GIRARD H., Présent et avenir agricole de la Basse-Égypte; un grand domaine dans le Delta. Thèse/ Institut agricole de Beauvais/ Beauvais/ F./1901.

58 AMMAR A.M., The people of Sharqiyya; their racial history, serology, physical caracters, demography and conditions of life. Ph.D./ Manchester University/Manchester/ G.B./1940.

59 RASHIDI Z.R.G., Land reclamation in the Nile Delta; its geographical background and significance. MA/ Leeds Univ./ Leeds/ G.B./1940.

60 SAAD L, A geographical study of Minufiyya province: the physical character and the human reponse. Ph.D./ Reading Univ./ Reading/ G.B./1950. 
HAMDAN G.M., The population of the Nile Mid Delta, past and present: $a$ study in . dialectical integration in regional economy. Ph.D./ Reading Univ./ Reading/G.B./ 1953.

NASR N. al-S., Markaz Ashmoun: a study in agricultural geography. Ph.D./ LiverpoolUniv./ Liverpool/G.B./1954.

AL DANASOURI G.E., Qalyubiyya Province of lower Egypt. Ph.D./ Durham Univ./Durham/ G.By 1955.

WEHEBA A.F.M.M., The economic and social geography of Eastern Maryut, Egypt. Ph.D./ University College/ London/ G.B./1956.

EMBABI F.M.S., Population changes in the Nile Delta, 1927-1960. M. Litt./ Bristol Univ./ Bristol/G.B./1968.

MENZEL G., Die Organisation, Leitung und Planung staatlicher Landwirtschaftsbetriebe in den Neulandgebieten der ARÄ unter bes. Berücks. des Agrarsektors Mariut, 1976 (Organisation, direction et planification des exploitations agricoles étatisées dans les régions de nouvelles terres de la République Arabe d'Égypte, d'après le cas du secteur agricole de Maryut, 1976). Dissert./ Leipzig Univ./ Leipzig/ D./1976.

RUF T., La formation agraire égyptienne de la fin du XVIIIe siècle à nos jours: analyse du fonctionnement des exploitations dans le nord du Delta et en Moyenne-Égypte. Th. 3ème CI Univ. de Paris 1/ Paris/ F./1983.

CUNO K.M., Landholding, society and economy in rural Egypt, 1740-1850: a case study of Al Daqhaliyya Province. Ph.D./ Univ. of California/ Los Angeles, CA./U.S.A./ 1985.

69 FANCHETTE S., Le Delta du Nil : densités de population et urbanisation des campagnes. Th. géo. (nouv.rég)./ Univ. Paris Vlll/St Denis/ F./1992.

\subsection{Sa'id (moyenne et Haute-Égypte)}

SADEK D.A., The historical geography of Giza province. M.A./ Manchester Univ./ Manchester/ G.B./1948.

EZZ M.S.A.E., The northern part of Aswan Province. Ph.D./ Durham Univ./ Durham/G.By 1953. HAMMOUDA I.S., Regional development of the Aswan region of Egypt, with special reference to the Aswan High Dam. Ph.D./ St. Andrews Univ. / St Andrews / Scotland, G.B./ 1973.

2 SERIEYS G., La nouvelle Nubie. Etude géographique. Th. 3ème C./ Univ. De Montpellier III/ Montpellier/ F./1974. EL ATTAR M., Les Nubiens d'Égypte : un exemple de changement social. Th. 3ème C. / Univ. de Caen/ Caen/ F./1980.

3 ALLEAUME G., Les provinces de Giza et de Beni Suef dans les «Khitat » de 'Ali Pacha Mubarak: introduction, traduction et essai d'interprétation. Th. 3ème C.I Univ. d'Aix-Marseille 1/ Aixen-Provence/ F./1981.

RUF T., La formation agraire égyptienne de la fin du XVIIIe siècle à nos jours: analyse $d u$ fonctionnement des exploitations dans le nord du Delta et en Moyenne-Égypte. Th. 3ème C./ Univ. de Paris 1/ Paris/ F./ 1983.

BREWER D.J., Cultural and environmental change in the Fayyum, Egypt : an investigation based on faunal remains. Ph.D./ Univ. of Tennessee/ Knoxville, TN./ U.S.A./ 1986.

MOHAMMED E. Abd al-A., Entwurf einer Entwicklungsstrategie für das Niltal Ägyptens: dargestellt am Beispiel des Provinz Asyut (Esquisse de stratégie de développement pour la 
vallée égyptienne du Nil, à partir de l'exemple de la province d'Asyut). Dissert./ Technische Univ./ Berlin/ D./1989.

\subsection{Oasis et déserts}

MITWALLI M.M., A geographical study of the Egyptian oases. Ph.D./ Liverpool Univ./ Liverpool/ Q.B./ 1938.

ABOU ZAYD A.M., The Great Oasis: a study of the social institutions of AI Kharga, an egyptian oasis of the Western Desert. Ph.D./ Oxford Univ./ Oxford/ G.B.I 1957.

SETEHA M.M.A., Recent economic development in the eastern desert of Egypt, U.A.R.: a study in economic geography. Ph.D./ Manchester Univ./ Manchester/ G.B./1966.

AL SAYAD M.T., Entwicklungsmöglichkeiten des Siediungsstruktur in ländlichen Räumen Ägyptens unter Berücksichtigung des Fremdenverkers, dargestellt am Beispiel der Region Marsa Matruh (Possibilités de développement de la structure des établissements humains dans les espaces ruraux égyptiens, sous leur rapport avec le tourisme, d'après l'exemple de la région de Marsa Matruh). Dissert./ Tech. Hochschule, Fak. f. Bauwesen/ Aachen/ D./ 1979.

\subsection{Terres nouvelles (voir 3.3.3.1.2. Bonification et terres nouvelles)}

\section{3. Économie agraire de l'Égypte}

\subsection{La statistique agricole}

HINDY M.K., Application of some sampling techniques to improve the collection of agricultural data in Egypt. Ph.D./ Univ. of Wisconsin/ Madison, WIS./ U.S.A./ 1957.

BADR M.I., Developing statistical methods and systems of the agricultural sector in Egypt as a part of planning for general economic development. Ph.D./ Univ. of Wisconsin/ Madison, WIS./ U.S.A./1960.

\subsection{Tableaux globaux de l'économie agricole ( $x x^{e}$ siècle)}

NAHAS Y., Situation économique et sociale du fellah égyptien. Th. Dry Univ. de Paris/Paris/ F./1901.

EL NAGGAR M.S., Essai sur le fellah et le travail manuel en Égypte. Th. Dr. Eco./ Univ. de Lyon/Lyon/F./1913.

HEIKAL I.S., Die Landwirtschaft in Ägypten (L'agriculture en Égypte). Dissert./ Berlin Univ./ Berlin/ D./1926.

OAF M.N., Allgemeine Grundlagen und Betriebsorganizationen der âgyptischen Landwirtschaft (Traits généraux, fonctionnement et organisation de l'agriculture égyptienne). Dissert./ Frankfurt Univ./ Frankfurt/ D./1927.

87 KAUFMANN A., Ewiges Stromland; Land und Mensch in Ägypten (L'éternel pays fluvial; la terre et l'homme en Égypte). Dissert./ Giessen Univ./ Giessen/ D./ 1929. 
FARID LA., The introduction of perennial irrigation in Egypt and its effects on the rural economy and population problems of the country. Ph.D./ University College/London/ G.B./ 1937.

EBERLI H., Die Veränderungen im Anbau der ägypt. Nahrungspflanzen, darg. Im Zusammenhang mit der Zunahme der ägypt. Bevölkerung, dem Wandel im ägypt. Bewâsserungssystem und in der Landwirtshaft seit Ende des 19.J. (Les transformations de l'agriculture vivrière égyptienne et leur rapport avec l'accroissement de la population et le changement du système d'irrigation et d'agriculture depuis la fin du XIXe siècle). Dissert./ Zurich Univ./ Zurich/ S./1939.

AL ZALAKI M.M.M., An analysis of the organization of Egyptian agriculture and of its influence on national economic and social institutions. Ph.D./ Univ. of California/Berkeley, CA./ U.S.A./ 1941.

HALPAP P., Struktur, Leistung und Entwicklung der âgyptischen Landwirtschaft (Structure, performances et développement de l'agriculture égyptienne). Dissert./ Berliner Univ./ Berlin/ D./1958.

EL BEBLAWI H., L'inter-relation agriculture-industrie et le développement économique en Égypte. Th. État/* / * F./1964.

3 GRIENIG H., Zur Agrarumgestaltung in einigen Lândern des nahen und mittleren Ostens, unter besonderer Berûcksichtigung der VAR (Âgypten) (Sur les transformations agraires dans quelques pays du Proche et Moyen-Orient, et particulièrement en République Arabe Unie/Égypte). Dissert./ Leipzig Univ./Leipzig/ D./1966.

94 MOHIE EL DIN Y.A., Egyptian agriculture: a case of arrested development. Ph.D./Univ. of Wisconsin/ Madison, WIS./ U.S.A./1966.

RUF T., SURDON C, Contribution à l'étude du système agraire de l'Égypte indépendante; le développement agricole égyptien depuis la fin du XVIIIe siècle. Mém. DAA/ INAPG/ Paris/ F./ 1979.

6 LAVERGNE M., L'agriculture égyptienne dix ans après l'achèvement du Haut-Barrage d'Aswan. Th. 3ème C./Univ. de Paris VIl/ Paris / FJ 1980.

EL-GUNDY M., L'agriculture et l'économie dualiste: aspects théoriques et application au cas égyptien. Th. État/ Univ. Aix-Marseille III/Aix-en-Provence/ F./1983.

DE SAINTE MARIE Ch., Les agricultures égyptiennes. Th. 3ème C./ IEDES, Univ. De Paris 1/ Paris/F./1987. LOFGREN H. L., A quadratic programming study of Egyptian agriculture. Ph.D./ Univ. of Texas/ Austin, TXJ U.S.A./1990.

\subsection{La production agricole}

\subsubsection{La production agricole, analyses générales}

SEDKY A., L'agriculture égyptienne ; la production. Th.Dr.Eco./ Sorbonne/ Paris/ F./ 1958.

OMAR N., Etude du surplus agricole en RA.U (1952-1967). Th. Eco./ * / * / F./1970.

MAKARY S.R., The possibility of increasing agricultural productivity in Egypt. Ph.D./ Leicester Univ./ Leicester/ G.B./1979.

ABOU SAAD M., Beitrag zu quantitativen Analyse von pflänzlicher Produktion und Agrarpreisen in der ARÄ mit Hilfe eines prozessanalystischen Modellansatzes (Contribution à l'analyse quantitative de la production végétale et des prix agricoles en République 
Arabe d'Égypte à l'aide d'un modèle d'analyse dynamique). Dissert./ Bonn Univ./ Bonn/ D./1980.

SHENG T.S., A risk-goal programming approach to whole farm analysis of small-scale farms in developing countries (the case of Abu Raia area in Kafr el Shaykh, Egypt). Ph.D./ Colorado State Univ./ Fort Collins, CO./ U.S.A./1982.

104 CHIAO Y.S., Frontier production function approaches for measuring efficency of Egyptian farmers. Ph.D./ Univ. of California/ Davis, CA./ U.S.A./1985.

SADEK A.M., Supply response in egyptian agriculture (1969-1978). Ph.D./ Oxford Univ./ Oxford/G.B./1985.

\subsubsection{Les produits agricoles}

\subsubsection{Géographie des cultures agricoles}

SELIM H.K., Post war changes in the agricultural geography of Egypt. M.A./ Liverpool Univ./ Liverpool/G.B./1939.

SIMONS P., Die Entwicklung des Anbaus sowie die Verbreitung und Bedeutung des Nutzpflanzen in der Kulturlandschaft der âgypten Nilstromoase von 1800 bis zur Gegenwart, eine agargeographische Untersuchung (Le développement de la culture et l'élargissement et la signification des plantes utiles dans le paysage cultural de l'oasis fluviale nilotique égyptienne de 1800 à nos jours ; une rech. de géo. agr). Dissert./ Köln Univ./ Köln/ D./ 1967.

DE SAINTE MARIE Ch., Les agricultures égyptiennes. Th. 3ème C./ IEDES, Univ. de Paris 1/ Paris/F./1987.

\subsubsection{Les différentes cultures}

\subsection{Coton}

ZOHNI A., Le coton égyptien, son importance dans la vie économique, son rôle dans la vie sociale. Th.Dr./ Univ. de Lyon/ Lyon/1921.

110 MANSOUR M.S., Baumwollanbau oder Kornanbau in Ägypten? (Culture du coton ou culture du blé en Égypte ?). Dissert./ Bonn Univ./ Bonn/ D./1924.

BAUMANN E., Untersuchungen an ägyptischen Baumwollsorten versiedener Ernten (Recherches sur les variétés de coton égyptien de différentes récoltes). Dissert./ Technische Hochschule/ Zurich/ S./1927.

112 TEMPLETON J., The perennial cultivation of cotton with special reference to the cultivation of ratoons in Egypt. D.Sc./ Edinburgh Univ./ Edinburgh/ G.B./1927.

113 FIKRY A., The wilt desease of egyptian cotton caused by various species of fusarium. Ph.D./ Cambridge Univ./ Cambridge/ G.B./1931.

114 ABOU STEIT H., La politique cotonnière de l'Égypte. Th.Dr.Eco./ Univ. de Paris / Paris / F./ 1932.

115 LINDNER Ph.Fr., Über Wirtschaftswandlungen in Âgypten, an Beispielen von Zuckerrohr, Weizen und Baumwolle (Les changements économiques en Égypte à partir des exemples de la culture de la canne à sucre, du froment et du coton). Dissert./ Wien Univ./ Wien/ ö./1937. 
HAFEZ M.A.R., The Alexandria cotton market. M.A./ Manchester Univ./ Manchester/G.B./ 1938.

EMAN A., L'industrie cotonnière en Égypte. Th.Sc.Eco./ Ecole de droit du Caire-Université de Paris / Le Caire-Paris / F./1942.

AHMED A.M., Cotton production with special reference to Egypt. M.Sc./ London External Degree/ London/ G.B./1946.

HALLETT E., Cotton finance and its relation to the currency and credit system of Egypt. Ph.D./ London External Degree/ London/ G.B./1946.

SHABANA Z.M., Competitive situation of Egyptian cotton in the American market. Ph.D./ Univ. of Wisconsin/ Madison, WIS./ U.S.A./1951.

AHMED E.E.D.H., Prices and government controls in the marketing of egyptian cotton. Ph.D./ Bristol Univ./ Bristol/ G.B./1954.

MEZ Th., Der Markt ägyptischer Baumwolle unter besonderer Berücksichtigung seiner Struktur (Le marché du coton égyptien envisagé en particulier du point de vue de sa structure). Dissert./ Freiburg Univ./ Feiburg/ S./1954.

HASSAN Sh.A., Möglichkeiten zur Verbesserung der ägyptischen Geflügelwirtschaft, unter bes. Berûcksichtigung der Verwendung von Baumwollsaatmelh (Possibilité d'amélioration de l'élevage de volaille en Égypte, en particulier grâce à l'emploi de la farine de graine de coton). Dissert./ Hohenheim Univ./ Hohenheim/ D./1955.

GABALI F.Y., Le marché international du coton égyptien. Th.Dr.Eco./ * / * / F ./ 1956.

RADI M.A.K., The structure of the cotton market in Egypt. M.Sc. (Eco)/ London School of Economics/London/ G.B./1957.

AL-DIN S.S.N., A statistical analysis of some aspects of cotton production and marketing, with special reference to U.S.A. and Egypt. Ph.D./ London School of Economics/ London/ G.B./ 1959.

SHAYAL S.E.M., An econometric study of price formation and demand for Egyptian cotton. Ph.D./ Oxford Univ./ Oxford/ G.B./1961.

OWEN E.R.J., Cotton production and the development of the economy in 19th. century Egypt (1821-1914). Ph.D./ Oxford Univ./ Oxford/ G.B./1966.

JACOB M., Pilzliche Erkrankungen der Baumwollkeimlinge in Ägypten (Les maladies micosiques des germes de coton en Égypte). Dissert./ Hohenheim Univ./Hohenheim/ D./1967.

KHEIR EL DIN H.AA, Quadratic programming approach to the problem of optimal use and pricing of cotton in Egypt. Ph.D. / Massachusetts Inst, of Techn./Cambridge, MA./ U.S.A./ 1968.

MEKKY S.I., A comparative study of the health of women employed in the english and egyptian cotton industries. Ph.D./ School of Hyg. \& Tropical Med./ London/G.B./1968.

MOUSSA A.R.A., The manufacturing of cotton for export in the U.A.R. (Egypt). Ph.D./Reading Univ./ Reading/ G.B./1968.

MANSOUR A.H., Economical and statistical analysis of raw cotton exports under bilateral trade and payments agreements in Egypt in the period 1948-1964. Ph.D./ Saint Andrews Univ. / St Andrews / Scotland, G.B./1971. 

U.S.A./1983.

\subsection{Céréales, blé} ô./1937. 1949. D./1983. U.S.A./1985. Univ./ Bonn/ D./1985.

ABOUL ELA N., The development of raw cotton and cotton textiles in Egypt, with special reference to the period since 1972. M.Sc.Eco./ W.Swansea Univ./G.B/1975.

ISSA F.M., Cotton in the egyptian economy, with special reference to the land allocation problem (1952-1974). Ph.D./Sussex Univ./G.B./1980.

MOSTAFA D.M., Die Ausnutzung komparativer Vorteile in Entwicklungsländern, untersucht am Beispiel des Aussenhandels Ägyptens mit Baumwolle und Baumwollerzeugnissen (L'exploitation des avantages comparatifs dans les pays à économie planifiée, à partir de l'exemple du commerce extérieur égyptien du coton et de ses sous-produits). Dissert./ Hochschule für Ökonomie/ Berlin/ D./1983.

MOUKHTARI F.L., Government intervention, price manipulation and agricultural productivity: a comparative analysis of wheat and cotton productivity in Iraq and Egypt. Ph.D./ Univ. of Delaware/ Newark, DE./ U.S.A./1983.

ODHIAMBO M.O., Production risk and decision making: testing alternative econometric models with evidence from Egyptian cotton production. Ph.D./Univ. of California/ Davis, CA./

MANSOUYR M.S.al-D., An economic analysis of the world market for Egyptian cotton. Ph.D./ Oregon State Univ./ Cornvallis, OR./ U.S.A./1984.

BEIGHLEY D.H., Short-branch and cluster habit inheritance in crosses of upland and Egyptian cotton. Ph.D./ New Mexico State Univ./ Las Cruces, NM./ U.S.A./1986.

MANSOUR M.S., Baumwollanbau Oder Kornanbau in Âgypten? (Culture du coton ou culture du blé en Égypte ?). Dissert./ Bonn Univ./ Bonn/ D./1924.

LINDNER Ph.Fr., Ûber Wirtschaftswandlungen in Âgypten, an Beispielen von Zuckerrohr, Weizen und Baumwolle (Les changements économiques en Égypte à partir des exemples de la culture de la canne à sucre, du froment et du coton). Dissert./Wien Univ./ Wien/

AYAD M.A.Gh., Correlated inheritance of reaction to stem rust and other caracters in crosses between Egyptian varieties of weath. Ph.D./ Univ. of Minnesota/ Minneapolis, MIN./USA./

MOUKHTARI F.L., Government intervention, price manipulation and agricultural productivity: a comparative analysis of wheat and cotton productivity in Iran and Egypt. Ph.D./ Univ. of Delaware/ Newark, DE./ U.S.A./1983.

TARYAL A.R.M., Die Verwendung hochertragreicher Getreidesorten (Weizen, Mais und Reisj und ihr Beitrag zur Verbesserung der Nahrungsmittelversorgung in der ARÄ (L'emploi des variétés céréalières à haut rendement (blé, maïs et riz) et leur contribution à l'amélioration de l'approvisionnement vivrier en Égypte). Dissert./ Bonn Univ./ Bonn/

6 ALSAFFY M.T.al-A., Demand for wheat and rice in selected Arab countries: the current situation and projections to year 2000. Ph.D./ Washington State Univ./Pullman, WA./

NAGA S.A.A.al-D., Getreideversorgung in Âgypten in den Jahren 1980 bis 1990 (Approvisionnement en céréales de l'Égypte dans les années 1980-1990). Dissert./ Bonn 


\subsection{Canne à sucre} Philadelphia, PA./ U.S.A./1958.

\subsection{Oignons}

ABDALLAH H.H., Marketing of desydrated onions with special reference to Egypt. M.Sc./ New Castle upon Tyme Univ./New Castle u. Tyne/ G.B./1975.

ABDEL HALIM S.A., Untertuchungen ûber Zwiebelproduktion und Preisgestaltung in der ARÄ unter Berûcksichtigung der Weltmarktsituation (Recherches sur la production d'oignons et la formation des prix en République Arabe d'Égypte, en regard de la situation du marché mondial). Dissert./ Halle Univ./ Halle/ D./ 1980. 
3.3.2.2. Tabac

ABOU AL FETOUH M.F. A quantitative study of the tobacco industry in Egypt, with particular reference to the E.T.C. farm. Ph.D./ Lancaster Univ./ Lancaster/ G.B./1976.

\subsection{Volailles}

HASSAN Sh.A., Môglichkeiten zur Verbesserung der ägyptischen Goflügelwirtschaft; unter bes. Berücks. der Verwendung von Baumwollsaatmehl (Possibilités d'amélioration de l'élevage de volailles en Égypte, en particulier grâce à l'emploi de la farine de graine de coton). Dissert./ Hohenheim Univ./ Hohenheim/D./1955.

\subsection{0. Élevage}

BAUER H., Die Tierzucht in Ägypten (L'élevage en Égypte). Dissert./ Berlin Univ./Berlin/ D./ 1940 .

SIRRY I., A study of the methods followed in the development and improvment of dairy herds of cattle with special reference to the sub-trapical countries (EGYPT). Ph.D./ Reading Univ./ Reading/ G.B./1943.

FARMER Ch.M., The potential role of livestock in a nuclear-powered agro-industrial complex in the UAR. Ph.D./ Univ. of Tennesse/ Knoxville, TE./ U.S.A./1969.

RAGAB A.al-M., Die viehwirtschaftliche Ressourcen der Arabischen Republik Ägyptens und Môglichkeiten einer verstârkten volkswirtshaftlichen Nutzung (Les ressources économiques en bétail de la République Arabe d'Égypte et les possibilités de renforcement de leur utilisation économique). Dissert./Leipzig Univ./ Leipzig/ D./1978.

ABOU RAS R.B., Angebots-und Nachfrageanalyse für Rind-und Bûffelfleisch in Ägypten von 1969-1979 (Analyse de l'offre et de la demande de viande de boeuf et de buffle en Égypte de 1969 à 1979). Dissert./ Giessen Univ./ Giessen/ D./1979.

166 RADWAN A.A., Bedingungen, Funktionen und Entwickelungsmöglichkeiten der tierischen Produktion in Âgypten (Conditions, fonctions et possibilités de développement de la production animale en Égypte). Dissert./Georg-Augustus Univ./ Göttingen/ D./1987.

\subsection{Fourrages}

GROSSE R.A., Optimale Planung der Mischfutterindustrie in Âgypten; e. Beitrag zur Anwendung quantitativen Planungsmethoden in zentral gelenkten Wirtschaftsbereichen ( La planification optimale de l'industrie des fourrages mixtes en Égypte; une contribution à l'évaluation des méthodes de planification quantitatives dans les secteurs éco. à direction centralisée). Dissert./ Bonn Univ./ Bonn/ D./1980.

LEGEL S., Untersuchungen zur Verbesserung der Futterproduktion und Fûtterung von Wiederkäuern in Gebieten mit aridem und semiaridem Klima, dargestellt am Beispiel Syriens und Ägyptens (Recherches en vue de l'amélioration de la production fourragère et de l'alimentation des ruminants dans les régions à climat aride et semi-aride, d'après l'exemple de la Syrie et de l'Égypte). Dissert./ Leipzig Univ./ Leipzig/ D./1980. 


\subsection{Produits laitiers}


direction et planification des exploitations agricoles étatisées dans les régions de nouvelles terres de la République Arabe d'Égypte, d'après le cas du secteur agricole de Maryut, 1976). Dissert./Leipzig Univ./ Leipzig/ D./1976.

181 AL SIBAI K.B., An economic and operationnal study of the possibilities for limited mechanization on farms within the reclamed lands of the Nile Delta in Egypt. Ph.D./ Reading Univ./ Reading/ G.B./1978.

SHADI M., La stratégie du développement rural dans les nouvelles terres en Égypte. Th. État/ Univ. de Montpellier 1/ Montpellier/ F./1982.

TOMICH Th.P., Private land reclamation in Egypt: studies of feasibility and adaptative behavior. Ph.D./ Stanford Univ./ Stanford, CA./ U.S.A./1984.

SHALABY M.T., Problem in adaptation and behavioural change in new rural sertlements: a case study in Kharga Oasis, Egypt. Ph.D./ Nottingham Univ./ Nottingham/ G.B./1986.

\subsection{Utilisation et allocation des terres}

IRAHIM A.B.M., Planning of rural land use in the Nile Delta, with special reference to the effect of modern techniques. Ph.D./ Durham Univ./ Durham/ G.B./1960.

HEGAZI M., Rural settlement and land use planning in Faqus district of Egypt. Ph.D./ Reading Univ./ Reading/G.B./1969.

ASADI F.A.M., Socio-economic and political institutional factors influencing the land use pattern in Egypt. Ph.D./The Univ. of Michigan/ Ann Arbor, Ml. / U.S.A./ 1970.

RADWAN T.A.A., Rural settlement and land use planning in muhafazat El Qalyubiyya of the egyptian Nile Delta. Ph.D./ Wales Univ./ Aberystwyth/ G.B./1976.

ISSA F.M., Cotton in the egyptian economy, with special reference to the land allocation problem (1952-1974). Ph.D./Sussex Univ./G.B./1980.

KESHEN K.S., The impact of partial market pricing on land and water allocation in Egypt. Ph.D./ Oxford Univ./ Oxford/ G.B./1983.

\subsubsection{L'eau}

\subsection{Le Nil}

HASSAN H.I., The waters of the Nile. Ph.D./ University College/ London/G.B./1958. KLERRU W.A., The Nile waters question: political aspects of the utilization of the Nile

waters. Ph.D./ Univ. of California/ Los Angeles, CA./ U.S.A./ 1962.

HOSNI S.M., Legal problems of the development of the River Nile. Ph.D./ New York Univ./ New York, N.Y./ U.S.A./1957.

AL SHIBINI F.Z., Optimization models for the Nile water resources systems. Ph.D./ Southampton Univ./ Southampton/ G.B./1976.

MOHAMED O.M.A., The international regime of the River Nile. Ph.D./ Univ. of Southern California/ Los Angeles, CA./ U.S.A./1983.

AYEB H., Géopolitique d'un grand axe fluvial: le Nil (géopolitique des grands travaux d'aménagement de la Vallée du Nil : Égypte, Soudan). Th. Géo. (nouv. rég)./ Univ. Paris Vlll/ St Denis/1991. 


\subsubsection{2. le Haut-Barrage d'Assouan} Angeles, CA./ U.S.A./1971. Univ./ Innsbruck/ S./1975. Lyon/ Lyon/1928. College/ London/ G.B./1956.

HENERI W., Untersuchung über den weiteren Ausbau der elektrischen Energieversorgung in Ägypten, unter bes. Berûcks. der Kraftwerke am Aswan-Hochdamm und an des Kattara-Senke (Recherche sur l'extension future de l'approvisionnement en énergie électrique de l'Égypte, à partir du cas des centrales du Haut-Barrage d'Aswan et de la dépression de Qattara). Dissert./ Dresden Univ./ Dresden/ D./1962.

KANDEEL A.F.M., The "surplus " approach for project appraisal (an implication to the Aswan High Dam). Ph.D./ Univ. of Southern California/ Los Angeles, CA./ U.S.A./ 1966.

RABIE M.A., The impact of the Aswan High Dam on the economic development of the UAR. Ph.DJ Univ. of Houston/ Houston, TX./ U.S.A./1970.

NIAZY W.C., The economics of public projects in less developed countries: a case study of the Aswan Dam. Ph.D./ Univ. of Pennsylvania/ Philadelphia, PA./ U.S.A./ 1971.

SHIBL Y.A., The Aswan High Dam: benefit and cost analysis. Ph.D./ Univ. of California/ Los

HAMMOUDA I.S., Regional development of the Aswan region of Egypt, with special reference to the Aswan High Dam. Ph.D./ St. Andrews Univ./ St Andrews / Scotland, G.B./1973.

KISHAR H.A., Die Ausswirkungen des Aswan-Hochdammes auf die ägyptische Landwirtschaft (Les effets du Haut-Barrage d'Aswan sur l'agriculture égyptienne). Dissert./ Innsbruck

SAKR M. \& LUCIA M.C., Les déplacements de population provoqués par la mise en eau du HautBarrage d'Aswan. Th. 3ème C./ Univ. de Paris X/ Nanterre/ F./ 1975.

BRAHIM A.I., Le Haut-Barrage d'Assouan; analyse des effets socio-économiques d'un aménagement agricole. DESS Sc. éco./ Univ. de Montpellier/ Montpellier/ F./ 1977.

WHITTINGTON D., Water management in Egypt: a case study of the Aswan High Dam. Ph.D./ Univ. of Texas/ Austin, TXi U.S.A./1980.

SMITH S.E., Application of remote sensing techniques to the study of the impacts of the Aswan High Dam. Ph.D./ Univ. of Michigan/ Ann Arbor, Ml./ U.S.A./1982.

\subsection{Les régimes d'irrigation}

RICHTER K., Die Grundzûge der Bewâsserung Agypten's (Les traits principaux de l'irrigation en Égypte). Dissert./ Technische Hochschule/ Dresden/ D./ 1914.

MOHSEN M., L'irrigation au Soudan anglo-égyptien et en Égypte. Th. Et. (géo)./ Univ. de

FARID IA, The introduction of perennial irrigation in Egypt and its effects on the rural economy and population problems of the country. Ph.D./ University College/ London/ G.B./1937.

EBERLI H., Die Veränderungen im Anbau der Agypt. Nahrungspflanzen, darg. im Zusammenhang mit der Zunahme der Ägypt. Bevôlkerung, dem Wandel im Agypt. Bewässerungssystem \& in der Landwirtshaft seit Ende des 19.J. (Les transformations de l'agriculture vivrière égyptienne et leur rapport avec l'accroissement de la population et le changement du système d'irrigation et de l'agriculture depuis la fin du XIXe siècle). Dissert./ Zurich Univ./ Zurich/ D./ 1939.

INDIA M.E.A.A., Irrigation in modem Egypt: a study in economic geography. Ph.D./ University 
213 AL MENSHAWI M., Analyse und Entwicklungsmöglichkeiten von Bewàsserungsbetrieben auf Neuland, untersucht am Biespiel des Abis-Projekts, Agypten (Analyse et possibilités de développement des infrastructures d'irrigations dans les terres nouvelles, d'après l'exemple du projet de Abis, en Égypte). Dissert./ Hohenheim Univ./ Hohenheim/ D./ 1974.

\subsection{Mécanisation}

SAAB G., Motorisation de l'agriculture et production agricole en Égypte. Th. Dr. Sc.Eco./ V/F./ 1958.

215 AL SIBAI K.B., An economic and operationnal study of the possibilities for limited mechanization on farms within the reclamed lands of the Nile Delta in Egypt. Ph.D./ Reading Univ./ Reading/ G.B./1978.

216 BREMER J.A., Alternative for mechanization: public cooperative and the private sector in Egypt's agriculture. Ph.D./ Harvard Univ./ Cambridge, MA./ U.S.A./ 1982.

217 KERR J.M., Economic and institutionnal determinants of agricultural mechanization in Egypt. Ph.D./ Stanford Univ./ Stanford, CA./ U.S.A./1990.

\subsection{Investissements}

AL SHAFIE M.A., Population pressures on land and the problem of capital accumulation in Egypt. Ph.D./ Univ. of Wisconsin/ Madison, WIS./ U.S.A./1951.

MOHIE AL-DIN A.M.E.M.A., Agricultural investment and employment in Egypt since 1935. Ph.D./ London School of Economics/ London/ G.B./1967.

RADWAN S.M., Capital formation in Egyptian industry and agriculture, 1882-1967. Ph.DJ S.O.A.S./London/ G.B./1973.

BAROUDI E.G., Export crop production and investment in a traditionnal agricultural system: an analysis of the Egyptian case and its implications. B.Litt./ Oxford Univ./ Oxford/ G.B./1974.

\subsection{Innovation, conseil, vulgarisation agricoles}

ABDOU A.al-Gh.T., Zum effektiven System der Agitation, Agrarpropaganda und Agrarberatung fur del ökonomisch-gesellschaftlich-kulturelle Bewusstseinentwicklung auf dem Lande in der VAR (Un système effectif de mobilisation, de propagande et de conseil agraires en vue du développement de la conscience économique, sociale et culturelle dans la campagne égyptienne). Dissert./ Humboldt Univ./ Berlin/ D./1970.

NOURY M.M., The impact of the individual and rural community variables on the adoption of new farm practices in rural Egypt. Ph.D./ Iowa State Univ. of Sc.\& Tech./Ames, IO./USA./ 1973.

ABD AL MAQSOUD B.M., Social and psychological aspects of innovation among egyptian farmers. Ph.D./ Reading Univ./ Reading/ G.B./1977.

AZMY S.M., Probleme der Beratung bei der Fôrderung von Diffuzionprozessen in der Landwirtschaft Ägyptens ; empirische Untersuchungen im District Tanta, al Gharbiyya Provinz (Les problèmes de conseil en vue de l'élargissement des processus de vulgarisation dans la campagne égyptienne; recherches empiriques dans le district de Tanta, province de Gharbiyya). Dissert./ Hohenheim Univ./Hohenheim/ D./1980. 


\subsubsection{Les rapports de production dans l'agriculture}

\subsubsection{Structure et question agraires}


ATTA A.M.O., Agrarian Reform in Egypt since independance (1952-1965). Ph.D./ Oxford Univ./ Oxford/ G.B./1970.

OWEIS J.S., The impact of land reform on Egyptian agriculture (1952-1965). Ph.D./ Univ. of Utah/ Salt Lake City, UT./U.S.A./1970.

KHAIK M.A., Agrarian Reform in Egypt: a field study of the Agrarian Reform in two typical areas during the period 1953-1963. Ph.D./ London School of Economics/ London/ G.B./ 1971.

241 ARAFA N., Die sozialen und ökonomischen Folgen der Agrarreform in Ägypten. Ergebnisse einer Feldforschung an ehemaligen Landlosen in vier Ägyptens Dörfern (Les conséquences sociales et économiques de la Réforme agraire en Égypte ; résultats d'une recherche de terrain auprès de paysans précédemment sans terres dans quatre villages d'Égypte). Dissert./ Bonn Univ./ Bonn/ D./1972.

ABDULLATIF T., Ziele, Prozesse und Auswirkungen der Agrarreform in Kuba, Âgypten und der Volksrepublik China, eine Untersuchung auf der Basis des Tuma'schen Ansatzes zu einer Agrarreformtheorie (But, processus et effets de la Réforme agraire à Cuba, en Égypte et République Populaire de Chine ; une recherche sur la base de la contribution de Tourna à une théorie de la Réforme agraire). Dissert./ Göttingen Univ./ Göttingen/ D./1973.

FATHY A., Der Beitrag der Landwirtshaft und der Agrarreform zur socio-ökonomischen Entwicklung des ländlichen Âgyptens (La contribution de l'agriculture et de la Réforme agraire au développement socio-économique de l'Égypte rurale). Dissert./ Bonn Univ./ Bonn/ D./1975.

\subsubsection{Rapports de propriété}

ABDEL LATIF F., La loi des cinq feddans ou l'insaisissabilité de la petite propriété foncière en Égypte. Th.Dr.Eco./ Sorbonne/ Paris/ F./1914.

GABRA S., Esquisse de l'histoire économique et politique de la propriété foncière en Égypte. Th.Dr.Eco./ Univ. de Bordeau/ Bordeau/ F./1919.

SALEH M., La petite propriété rurale en Égypte. Th.Dr.Eco./ Univ. de Grenoble/ Grenoble / F./1922.

NEUVILLE J., La structure économique de la propriété foncière en Égypte. Th.Dr.Eco./ Univ. de Paris/ Paris / F./1948.

KHALIL S., Grundeigentum und Landreform in Âgypten (Propriété foncière et réforme agraire en Égypte). Dissert./ Bonn Univ./ Bonn/ D./1959.

GASCOU J., La possession du sol, la cité et l'État à l'époque protobyzantine et particulièrement en Égypte. Recherches sur l'histoire des structures agraires, de la fiscalité et des institutions aux Ve,Vle,Vlle siècles. Th. 3ème C./ Univ. de Paris 1/Paris/F./1975.

\subsubsection{Modes de tenure et de faire-valoir}

DAWOOD H.A., Economie aspects of land tenure in Egypt. Ph.D./ Michigan State College/ East Lansing, Ml./ USA./1950.

GHONEMY M.R., A study and analysis of farm tenancy in Egypt. M.A./ Univ. of Tennessee/ U.S.A./1951.

AL HALFAWI M.S., Land tenure in Egypt. B.Litt./ Lincoln College/ Oxford/ G.B./1953. 

Univ. de Paris / Paris / F./1948. Carolina/ U.S.A./1948. U.S.A/1983. Univ. de Paris 1/ Paris/ F./1983. Paris/ F./1987. H.C.I U.S.A./ 1954. Kiel/ D./1979.

YACCOB A.R.B., The evolution of land tenure and the agrarian economy in 19th. and early 20th century Egypt. M.Litt./ St Andrews Univ./ Univ. / G.B./1982.

CUNO K.M., Landholding, society and economy in rural Egypt, 1740-1850: a case study of AI Daqhaliyya Province. Ph.D./ Univ. of California/ Los Angeles, CA./ U.S.A/1985.

\subsubsection{Structure, taille et fonctionnement des exploitations}

SAFFA S., L'exploitation économique et agricole d'un domaine rural en Égypte. Th.Dr.Eco./

SELIM I., General relationship between the size of the farm and rural life with reference to the Lower Nile Vallee region and the southeastern region of the United States. M.A./ Univ. of North

SHENG T.S., A risk-goal programming approach to whole farm analysis of small-scale farms in developing countries (the case of Abu Raia area in Kafr el Shaykh, Egypt. Ph.D./ Colorado State Univ./ Fort Collins, CO./ U.S.A./1982.

HARDY I., GRAINDORGE M., Etude des systèmes de production paysans dans un village égyptien du Delta. Mém. DAA/ INAPG/ Paris/ F./1982.

NASR M., Betnebliches Produktionverhalten im Rahmen des àgyptischen Systems der staatlichen Anbauplanung in der Lanwirtschaft (Pratiques de production dans les exploitations agricoles dans le cadre du système égyptien de planification étatique de l'agriculture). Dissert./ Gôttingen Univ./ Göttingen/ D./1983.

ODHIAMBO M.O., Production risk and decision making: testing alternative econometric models with evidence from Egyptian cotton production. Ph.D./ Univ. of California/ Davis, CA./

RUF T., La formation agraire égyptienne de la fin du XVIIIe siècle à nos jours: analyse du fonctionnement des exploitations dans le nord du Delta et en Moyenne-Égypte. Th. 3ème C./

GLAVANIS K.R.G., Non capitalist relation and the small peasant household in rural Egypt. Ph.D./ Hull Univ./ Hull/ G.B./1984.

DE SAINTE MARIE Ch., Les agricultures égyptiennes. Th. 3ème C./ IEDES, Univ. de Paris 1/

ROUCHDY M., Peasants and merchants in Batra. The processus of economic diversification in an Egyptian village. Ph.D./ Univ. of Durham/ Durham/ G.B./ 1990.

\subsubsection{Revenus des exploitations agricoles}

GHONEMY M.R., Resource use and income in the Egyptian agriculture before and after the land reform under economic development aspects. Ph.D./ North Carolina State Univ./ Raleigh,

AL KAZAZ N., Möglichkeiten der Einkommenssteigerung in der Landschaft Ägyptens durch optimale regionale u. saisonale Verteilung des Wassers und Steigerung der Arbeitsproductivitàt, e.lineare Programmierungsmodell (Possibilités d'augmentation des revenus dans la campagne égyptienne par la répartition optimale régionale et saisonnière de l'eau et l'augmentation de la productivité du travail ; mod. de prog. lin). Dissert./ Kiel Univ./ 
ARAMAN I., A model to develop egyptian agriculture to solve the problem of unemployment and low per capita income in egyptian agriculture. Ph.D./ Wales Univ./ G.B./1976.

HUSSEIN A.F.M., Die Steuerpolitik in der Landwirtschaft zur Erhôhung der Akkumulation und als Mittel der Umverteilung der Agrareinkommens in Entwicklungsländern am Beispiel Âgyptens (La politique fiscale appliquée à l'agriculture en vue de l'accroissement de l'accumulation et comme moyen de redistribution des revenus agricoles dans les pays en développement, l'ex. de l'Égypte). Dissert./ Hochschule fur Ökonomie/ Berlin/ D./ 1984.

HAIDER M.I., The impact of Egyptian agricultural policies on farm income and resource use. Ph.D./ Colorado State Univ./ Fort Collins, CO./ U.S.A./1982.

\subsubsection{Le système coopératif}

SOLIMAN M., Création et avenir des syndicats agricoles en Égypte. Th. Dr./ Univ. de Paris/ Paris/ F./1923.

AHMED T., Die Entwicklung des landwirtschaftlichen Genossenschaftswesens in Âgypten, verglichen mit anderen Ländem alter islamischer Kultur (Le développement de la coopération agricole en Égypte comparé avec celui existant dans d'autres pays de vieille culture islamique). Dissert./ Jena Univ./ Jena/ D./1924.

MIDHAT A., La coopération agricole en Égypte. Th. dr./ Univ. de Dijon/ Dijon/1926.

HAMOUDA KhAGh., Economic aspects of the application of cooperative farming in Egypt. Ph.D./ Univ. of Minnesota/ Minneapolis, MIN./ U.S.A./1956.

274 MURALT J. von, Entwicklung und Struktur des Genossenschaftswesens in Âgypten, unter bes. Berücks. der landwirtschaftlichen Genossenschaften (Développement et structure du secteur coopératif en Égypte, en particulier dans le domaine agricole). Dissert./ Marburg Univ./ Marburg/ D./1964.

WÖRZ J.G.F., Die genossenshafliche Produktionförderung in Âgyptèn als Folgeerscheinungen der Agrarreform und als neues Element der genossenshaflichen Entwicklung (L'élargissement de la production dans le cadre coopératif en Égypte comme phénomène lié à la Réforme agraire et comme nouvel élément du développement de la coopération agricole). Dissert./ Hohenheim Univ./ Hohenheim/ D./1966.

AL SHAGI AL-SH., Fôrderung der Landwirtshaft unterentwickelter Lânder durch genossenshaftliche Agrarproduktion, dargestellt am Beispiel Agyptens (Le progrès de l'agriculture des pays sous-développés grâce à la production agricole coopérative, d'après l'exemple égyptien). Dissert./ Hohenheim Univ./ Hohenheim/ D./1968.

AGAMI S., Organisation und Funktion der landwirtschaftlichen Genossenschatten in Ägypten (Organisation et fonction des coopératives agricoles en Égypte). Dissert./ Graz Univ./ Graz/ Ô./1973.

MITTWALLY S.H., Entwicklungsstand und Perspektiven des landwirtschaftlichen Genossenschaftswesens in Âgypten (Situation, développement et perspectives des coopératives agricoles en Égypte). Dissert./ Leipzig Univ./ Leipzig/D./1977.

BREMER J.A., Alternative for mechanization: public cooperative and the private sector in Egypt's agriculture. Ph.D./ Harvard Univ./ Cambridge, MA./ U.S.A./ 1982.

AL HAYDARY A.R., Der Einfluss der ländiichen Genossenschaftstypen in Âgypten auf die Bildung und Ausbildung ihrer Mitglieder (L'influence des types de coopératives rurales en 
Égypte sur la culture et la formation de leurs membres). Dissert./ Giessen Univ./ Giessen/ D./ 1983.

SAKR M.K., Âgyptens Landwirtschaftsgenossenschaften: Entwicklung, Struktur und ökonomische Bedeutung für das Entwicklungsprozess (Les coopératives agricoles en Égypte : développement, structures et signification économique pour le processus de développement). Dissert./ Frei Univ./ Berlin/ D./1985.

SAYED M.K., Der Einfluss landwirtschaftlicher Genossenschaften auf die Ernährungssituation ihrer Mitglieder; empiriche Erhebungen im Bezirk Samanud und in der Provinz Nord Tahrir, Âgypten (L'influence des coopératives agricoles sur la situation alimentaire de leurs membres ; enquête empirique dans le district de Samanud et dans la province de Tahrir nord). Dissert./ Giessen Univ./ Giessen/ D./1986.

\subsubsection{Crédit foncier et agricole}

MOHAMMED I.A., L'organisation du crédit foncier en Égypte; la société du crédit foncier égyptien. Th. dr./ Univ. de Paris/ Paris/1924. ZANNIS J., te crédit agricole en Égypte. Th. Dr. Sc.Eco./ Univ. Paris/ Paris/ F./1936.

\subsection{LE COMMERCE DES PRODUITS AGRICOLES}

\subsubsection{Les prix agricoles}

LEGRAND F., Les fluctuations de prix et les crises de 1907 et 1908 en Égypte. Th. dr./ Univ. de Nancy/ Nancy/1909.

THOMAS G.H., Changing values in egyptian agriculture from 1800 to the present time. M.A./ Birkbeck College/ London/ G.B./1939.

SHAYAL S.E.M., An econometric study of price formation and demand for egyptian cotton. Ph.D./ Oxford Univ./ Oxford/ G.B./1961.

KHEIR EL DIN H.A.A., Quadratic programming approach to the problem of optimal use and pricing of cotton in Egypt. Ph.D./ Massachusetts Inst, of Techn./ Cambridge, MA./ U.S.A./ 1968.

ABDEL HALIM S.A., Untertuchungen Ober Zwiebelproduktion und Preisgestaltung in der ARÂ unter Berûcksichtigung der Weltmarktsituation (Recherches sur la production d'oignons et la formation des prix en République Arabe d'Égypte, en regard de la situation du marché mondial). Dissert./ Halle Univ./ Halle/ D./ 1980.

ABOU SAAD M., Beitrag zu quantitativen Analyse von pflânzlicher Produktion und Agrarpreisen in der ARÂ mit Hilfe eines prozessanalystischen Modellansatzes (Contribution à l'analyse quantitative de la production végétale et des prix agricoles en République Arabe d'Égypte à l'aide d'un modèle d'analyse dynamique). Dissert. / Bonn Univ./ Bonn/ D./1980.

291 DETHIER J.J., The political economy of food price in Egypt. Ph.D./ Univ. of California/ Berkeley, CA./ U.S.A./1985. 


\subsubsection{Le marché des denrées agricoles}

\subsubsection{Extension de l'économie marchande rurale}

ROUCHDY M., Peasants and merchants in Batra. The processus of economic diversification in an Egyptian village. Ph.D./ Univ. of Durham/ Durham/ G.B./ 1990.

\subsubsection{Le marché du coton}

HAFEZ M.A.R., The Alexandria cotton market. M.A./ Manchester Univ./ Manchester/ G.BJ 1938.

MEZ Th., Der Markt ägyptischer Baumwolle unter besonderer Berûcksichtigung seiner Struktur (Le marché du coton égyptien envisagé en particulier du point de vue de sa structure). Dissert./ Freiburg Univ./ Feiburg/ S./1954.

GABALI F.Y., Le marché international du coton égyptien. Th.Dr. Sc.Eco./ * / */F./ 1956.

RADI M.A.K., The structure of the cotton market in Egypt. M.Sc.(Eco)/ London School of Economics/London/G.B./1957.

AL-DIN S.S.N., A statistical analysis of some aspects of cotton production and marketing, with special reference to U.S.A. and Egypt. Ph.D./ London School of Economics/ London/ G.B./ 1959.

MOUSSA A.R.A., The manufacturing of cotton for export in the U.A.R. (Egypt). Ph.D./ Reading Univ./ Reading/ G.B./1968.

MANSOUR A.H., Economical and statistical analysis of raw cotton exports under bilateral trade and payments agreements in Egypt in the period 1948-1964. Ph.D./Saint Andrews Univ./ St Andrew I G.B.11971.

AL ABASSY H., Zur Entwicklung des Absatzes landwirtschaftlicher Erzeugnisse in Ägypten, insbesondere dargestellt am Beispiel des Absatzes von Baumwolle (Le développement des débouchés pour les produits agricoles en Égypte, en particulier d'après l'exemple des débouchés du coton). Dissert./ Leipzig Univ./ Leipzig/D./1972.

MOSTAFA D.M., Die Ausnutzung komparativer Vorteile in Entwicklungsländem, untersucht am Beispiel des Aussenhandels Ägyptens mit Baumwolle und Baumwollerzeugnissen (L'exploitation des avantages comparatifs dans les pays à économie planifiée, à partir de l'exemple du commerce extérieur égyptien du coton et de ses sous-produits). Dissert./ Hochschule für Ökonomie/ Berlin/ D./1983.

\subsubsection{Le marché des denrées autres que le coton}

MOHAMMED M.al-S., The structure and function of agricultural export trade in the Egyptian economy. Ph.D./ Univ. of California/ Berkeley, CA./ U.S.A./1944.

HAJJAR N.G., Intraregional trade in the Arab Near East with emphasis on the products of agriculture. Ph.D./ Univ. of California/ Berkeley, CA./ U.S.A./1959.

BAROUDI E.G., Export crop production and investment in a traditionnal agricultural system: an analysis of the egyptian case and its implications. B.Litt./ Oxford Univ./ Oxford/ G.B./1974.

RANDAQ H., Die agrarwirtchaftliche Entwicklungen im Irak und in Âgypten: eine vergleichende Analyse unter besonderer Berücksichtigung der landwirtschaftlichen Märkte (Le développement agricole en Irak et en Égypte: une analyse comparée prenant en 
particulier en considération les marchés agricoles). Dissert./ Erlangen Nûrnberg Univ./ Nümberg/ D./1974.

RIZQ BA, A study of some aspect of the marketing of rice with special reference to Egypt. Ph.D./ Univ. of Wales/ Aberystwyth/ G.B./1980.

AL-MALlAH G., Die volkswirtschaftliche Bedeutung des Agraraussenhandels in Ägypten: Analyse und Zukunftsaussichten (La signification politico-économique du commerce agricole extérieur de l'Égypte: analyse et perspectives d'avenir). Dissert./Giessen Univ./Giessen/ D./1981.

SAHEH H.M., Strukturelle Veränderungen der âgyptischen Zahlungsbilanz: Entwicklung, Probleme, Ursachen und Möglichkeiten ihrer Verbesserung, dargestellt unter Berücksichtigung der Role des Agrarsektors (Changements structurels dans la balance des paiements égyptienne, évolution, problèmes, facteurs et possibilités de son amélioration, en mettant l'accent sur le rôle du secteur agraire). Dissert./ Hochschule für Ökonomie/ Berlin/ D./1983.

\subsection{Consommation et demande alimentaire}

\subsubsection{La demande alimentaire}

\subsubsection{Pression démographique et demande alimentaire}

REDA Kh.S., Food and the Egyptian population. Ph.D./ Havard University/ Cambridge, MA./ U.S.A./1947.

310 LOESCH H., Ernährung und Bevölkerung in der Entwicklung der âgyptischen Wirtshaft, eine Untersuchung der gegenwartigen Bedingungen der wirtschaftlichen Wachstum Âgyptens (Alimentation et population dans le développement de l'économie égyptienne; une recherche sur les conditions actuelles de la croissance économique de l'Égypte). Dissert./ Mûnchen Univ./ Mûnchen/ D./1966.

311 AL ESSAWY F.M., Population and food resources in Menoufiyya, Egypt. Ph.D./ Durham Univ./ Durham/ G.B./1985.

\subsubsection{Analyse de la demande et modèles de consommation alimentaire}

HASSAN R.A.R., An analysis of the demand for food in Egypt. Ph.D./ Michigan State Univ./ East Lansing, Ml./ U.S.A./1969.

MUSTAFA Kh., Le modèle de consommation alimentaire en Égypte rurale (1952-1974), DESS Sc.éco./ Univ.de Montpellier/ Montpellier/ F./1977.

314 ABOU RAS R.B., Angebots-und Nachfrageanalyse für Rind-und Bûffelfleisch in Ägypten von 1969-1979 (Analyse de l'offre et de la demande de viande de boeuf et de buffle en Égypte de 1969 à 1979). Dissert./ Giessen Univ./ Giessen/ D./1979.

ALDERMAN H.H., Allocation of goods through non-price mechanisms: implications of rationing and waiting times in Egypt. Ph.D./ Harvard Univ./ Cambridge, MA./ U.S.A./1984.

316 (ALSAFFY M.T. al-A., Demand for wheat and rice in selected Arab countries: the current situation and projections to year 2000. Ph.D./ Washington State Univ./ Pullman, WA./ U.S.A./1985. 


\subsubsection{Situation alimentaire et approvisionnement}

\subsubsection{Produits agricoles peu élaborés}

Égypte/Monde arabe, 12-13 | 1993 Toulouse II/ Toulouse/ F./1983. D./1983. Univ./ Bonn/ D./1985. Philadelphia, PA./ U.S.A./1958.

\subsubsection{Dépendance alimentaire}

AMIN G. al-D.A., The food problem and economic development in Egypt since 1935. Ph.D./ London School of Economics/London/ G.B./1964.

KUHL B.E., Lebensmittelkontrole in Ägypten im Vergleich $z u$ Sudan, Tunisien und Bundesrepublik Deutschland (Le contrôle des produits vivriers en Égypte comparé à celui pratiqué au Soudan, en Tunisie et en RFA). Dissert./ Giessen Univ./ Giessen/ D7 1982.

ELFAKIR A., Disettes et famines en Égypte aux XlVe et XVe siècles. Th. 3ème C./ Univ. de

TARYAL A.R.M., Die Verwendung hochertragreicher Getreidesorten (Weizen, Mais und Reis) und ihr Beitrag zur Verbesserung der Nahrungsmittelversorgung in der ARÄ (L'emploi des variétés céréalières à haut rendement (blé, maïs et riz) et leur contribution à l'amélioration de l'approvisionnement vivrier de l'Égypte). Dissert./ Bonn Univ./ Bonn/

BAKFALOUNI T., Les effets démographiques des épidémies, des guerres et des disettes au Proche-Orient du VIle au XIXe siècle. Th. 3ème CI EH ESS/ Paris/ F./1984.

RICE K.S., The allocation, dietary intake and productivity in a schistosomiasis stressed Egyptian village. Ph.D./ Univ. of Utah/ Salt Lake City, UT./ U.S.A./1985.

NAGA S.A.A.al-D., Getreideversorgung in Ägypten in den Jahren 1980 bis 1990 (Approvisionnement en céréales de l'Égypte dans les années 1980-1990). Dissert./ Bonn

SAYED M.K., Der Einfluss landwirtschaftlicher Genossenschaften auf die Ernâhrungssituation ihrer Mitglieder; empiriche Erhebungen im Bezirk Samanud und in der Provinz Nord Tahrir, Âgypten (L'influence des coopératives agricoles sur la situation alimentaire de leurs membres ; enquête empirique dans le district de Samanud et dans la province de Tahrir nord). Dissert./ Giessen Univ./ Giessen/ D./1986.

\subsubsection{Produits des industies agro-alimentaires}

AFIFI A.A., Technological and economic study for the promotion and development of food industies in Egypt. Ph.D./ Univ. of Massachussets/ Amherst, MA./ U.S.A./ 1949.

GARNICK D.H., Middle Eastern citrus industries and their markets. Ph.D./ Dropsie College/

ELKURDI M.K., Stratégie d'exportations des entreprises égyptiennes de conserves alimentaires. Th. 3ème C./Univ. Paris IX/ Paris/ F/1978.

\subsubsection{Dépendance, sécurité et aide alimentaire}

CICEKDAG MA, The dependance of Middle-Eastern countries on foreign food Ph.D./ Univ. of California/ Santa Barbara, CA./ U.S.A./1980.

ABDEL FATTAH MOSTAFA Kh., La dépendance alimentaire de l'Égypte (1952-1977). Th. État/ Univ. de Montpellier 1/ Montpellier/ F./1983. 


\subsubsection{Sécurité et autosuffisance alimentaire}

EMARAH R. al-S. Potential self-sufficiency in major Egyptian crops: necessary production and price policies as estimated by an econometric model. Ph.D./ Iowa Sta. Univ. of Sc. \& Tech./ Ames, IO./ U.S.A./1982.

HASHEM A.al-R.M., Egyptian food system development: simulation of alternative strategic plans (or Egyptian food security. Ph.D./ Kansas State Univ./ Manhattan, KS./U.S.A./1986.

RAMADAN B.I., Food security in the Arab world: its signifiance and means of attainment. Ph.D./ Cornell Univ./ Ithaca, N.Y./ U.S.A/1986.

EL BATRAN M.M., The impact of alternative policies on the food gap for strategic crops in Egypt. Ph.D./ Colorado State Univ./ Fort Collins, CO./ U.S.A./1989.

\subsubsection{Aide alimentaire}

FAULKNER C.P., The economic effects of United States Public Law 480 in the the UAR. Ph.D./ Univ. of Utah/ Salt Lake City, UT./ U.S.A./1969.

\section{Développement, planification et politique agricoles}

\subsection{Développement et planification agricole}

\subsection{1. À l'échelle nationale}

GHONEMY M.R., Resource use and income in the Egyptian agriculture before and after the land reform under economic development aspects. Ph.D./ North Carolina State Univ./ Raleigh, N.C./ U.S.A./1954.

ABDEL SAMIE H.M., Agrarreform und Massnahmen zur landwirtschaftlichen Entwicklung der Vereinigten Arabischen Republik und des Iraks (Réforme agraire et mesures concernant le développement agricole en République Arabe d'Égypte et en Irak). Dissert./ Kiel Univ./ Kiel/ D./1960.

BASHEER A.M., Approaches to the economic development of agriculture in Egypt Ph.D./ Univ. of Wisconsin/ Madison, WIS./ U.SA/1961.

AMIN G.al-DA, The food problem and economic development in Egypt since 1935. Ph.D./ London School of Economics/ London/ G.B./1962.

EL BEBLAWI H., L'inter-relation agriculture-industrie et le développement économique en Égypte. Th. État/* /* / F./1964.

ZAKI M.A.H., Economie development in the UAR and the role of the agricultural sector. Ph.D./ Ohio State University/ Athens, OH./ U.S.A./1965.

AL DEEMY M.S.M., Economic aspects of agricultural growth and development in the U.A.R. Egypt. M.Sc./ Aberdeen Univ./ Aberdeen/ G.B./1966.

ABDEL SAYED B.M., The potential use of fertilizer for the intensification and development of agriculture in the UAR. Ph.D./ New York Univ./ New York, N.Y./ U.S.A./ 1967.

ABOULELA H., Wirtschaltplan der V.A.R. in der 2. Hâlfte des 20 Jahrhunderts unter Berûcksichtigung der Landwirtschaft (La planification économique en République Arabe Unie dans la deuxième moitié du XXe siècle, en particulier dans le domaine agricole). Dissert./ Graz Univ./ Graz/ Ô./1968. 
344 AL SHAGI al-Sh., Förderung der Landwirtshaft unterentwickelter Lander durch genossenshaftliche Agrarproduktion, dargestellt am Beispiel Ägyptens (Le progrès de l'agriculture des pays sous-développés grâce à la production agricole coopérative, d'après l'exemple égyptien). Dissert./ Hohenheim Univ./ Hohenheim/ D./1968.

DIRAZ H.A.M., Taxation and agricultural development in the UAR. Ph.D./ Univ. of Pennsylvania/ Philadelphia, PA./ U.S.A./1968.

RABIE MA, The impact of the Aswan High Dam on the economic development of the UAR. Ph.D./ Univ. of Huston/ Houston, TX./ U.S.A./1970.

ABDEL RAOUF M.M., Die Agrarfrage und ihre Lôsung in der VAR, die Rolle des Staates bei der Planung und Leitung der Landwirtschaft zur Lôsung der Agrarfrage (La question agraire et sa résolution en République Arabe Unie; le rôle de l'État dans la planification et la direction de l'agriculture en vue de la résolution de la question agraire). Dissert./ Hochschule für Öconomie/ Berlin/D./1971.

RANDAQ H., Die agrarwirtchaftliche Entwicklungen im Irak und in Ägypten: eine vergleichende Analyse unter besonderer Berücksichtigung der landwirtschaftlichen Märkte (Le développement agricole en Irak et en Égypte: une analyse comparée prenant en particulier en considération les marchés agricoles). Dissert./ Erlangen Nûrnberg Univ./ Nürnberg/ D./1974.

349 FATHY A., Der Beitrag der Landwirtshaft und der Agrarreform zur socio-ökonomischen Entwicklung des làndlichen Àgyptens (La contribution de l'agriculture et de la Réforme agraire au développement socio-économique de l'Égypte rurale). Dissert./ Bonn Univ./ Bonn/ D./1975.

EL ROUBY R., Population, allocation des ressources humaines et développement rural: le modèle égyptien. Th. État/ Univ. de Rennes 1/ Rennes/ F./1980.

EL SEIDY A., Essai sur les aspects démo-économiques et le développement agricole dans la formation du capital en Égypte. Th. État/ Univ. de Nancy II/ Nancy/ F./ 1983.

MOSTAFA Y., La formation historique de la dépendance de l'Égypte(1820-1930); essai d'interprétation à partir du surplus agricole. Th. État/ Univ. de Montpellier 1/ Montpellier/ F./1983.

ARAMAN I., A model to develop egyptian agriculture to solve the problem of unemployment and low per capita income in egyptian agriculture. Ph.D./ Wales Univ./G.B./1976.

REDA A., Situationanalyse über Bestimmunggründe der bauerlischen Partizipation an Entwicklungsaktivitäten und Konsequenzen fur die landwirtschaftliche Beratung, untersucht in einer Dorfregion Mitt el Ägyptens (Analyse des facteurs déterminant la participation des paysans aux actions de développement et des conclusion à en tirer en vue du conseil agricole, d'après le cas d'une région rurale de Moyenne-Égypte). Dissert./ Technische Univy Berlin/ D./1985.

LAKOUCHA R., Développement économique et surplus agricole. Application au cas égyptien (1960-1980). Th. État/ Univ. d'Aix-Marseille III/Aix-en-Provence/ F./ 1986.

BUDDE A., Ägyptens Landwirtschaft im Entwicklungsprozess: eine kritische Analyse (L'agriculture égyptienne dans son processus de développement.; une analyse critique). Dissert./ Inst. für rurale Entwicklung, Georg-Augustus Univ./ Göttingen/ D./ 1987. 


\subsection{2. À L'échelle régionale et locale}

NASSOUHY M.G.E., Local autonomy under national planning: the Egyptian experience. Ph.D./ Univ. of Southern California/ Los Angeles, CA. /U.S.A./ 1965.

SETEHA M.M.A., Recent economic development in the eastern desert of Egypt, U.A.R.: a study in economic geography. Ph.D./ Manchester Univ./ Manchester/G.B./1966.

HAMMOUDA I.S., Regional development of the Aswan region of Egypt, with special reference to the Aswan High Dam. Ph.D./ St. Andrews Univ. / St Andrews / Scotland, G.B./1973.

NABIH M.E.S., Consideration for a regional development strategy in Egypt. M.Sc./ Strathclyde Univ./ Strathclyde/ G.B./1977.

IBRAHIM SH.M.A., Die Rolle der demokratishen Wirtschaftsplanung bei der Verwirklichung der Annäherung zwischen fortgeschrittenen und zurùckgebliebenen Gebieten in Âgypten (Le rôle de la planification économique démocratique en vue de la réduction des écarts entre régions égyptiennes avancées et arriérées). Dissert./ Halle Univy Halle/ D./1979.

SHADI M., La stratégie du développement rural dans les nouvelles terres en Égypte. Th. État/ Univ. de Montpellier 1/ Montpellier/ F./1982.

KASHWA M.I., Okonomische Aspekte der Regionalplanung und Vorschläge für die Entwicklungsplanung Ägyptens (Aspects économiques de la planification régionale et propositions en vue de la planification du développement en Égypte). Dissert./ Hannover Univ./ Hannover/ D./1984.

MOHAMMED E.Abd al-A., Entwurf einer Entwicklungsstrategie für das Niltal Ägyptens: dargestellt am Beispiel des Provinz Asyut (Esquisse de stratégie de développement pour la vallée égyptienne du Nil, à partir de l'exemple de la province d'Asyut). Dissert./ Technische Univ./ Berlin/ D./1989.

\subsection{Politiques agricoles ; État et agriculture}

\subsubsection{Analyses globales}

ABDOU A.al-Gh.T., Zum effektiven System der Agitation, Agrarpropaganda und Agrarberatung für dei ökonomisch-gesellschaftlich-kulturelle Bewusstseinentwicklung auf dem Lande in der VAR (Un système effectif de mobilisation, de propagande et de conseil agraires en vue du développement de la conscience économique, sociale et culturelle dans la campagne égyptienne). Dissert./ Humboldt Univ./ Berlin/ D./1970.

ABDEL RAOUF M.M., Die Agrarfrage und ihre Lösung in der VAR, die Rolle des Staates bei der Planung und Leitung der Landwirtschaft zur Lôsung der Agrarfrage (La question agraire et sa résolution en République arabe Unie; le rôle de l'État dans la planification et la direction de l'agriculture en vue de la résolution de la question agraire). Dissert./ Hochschule für Ökonomie/ Berlin/D./1971.

KHALIL E.S., Die Agrarpolitik Àgyptens seit der Revolution von 1952 unter besonderer Berûcksichtigung der Auswirkungen des arabischen Sozialismus (La politique agraire de l'Égypte depuis la Révolution de 1952, et en particulier les effets du Socialisme arabe). Dissert./ Heidelberg Univ./ Heidelberg/ D./1973.

HAIDER M.I., The impact of Egyptian agricultural policies on farm income and resource use. Ph.D./Colorado State Univ./ Fort Collins, CO./ U.S.A./1982. 
NASR M., Betriebliches Produktionverhalten im Rahmen des âgyptischen Systems der staatlichen Anbauplanung in der Lanwirtschaft (Pratiques de production dans les exploitations agricoles dans le cadre du système égyptien de planification étatique de l'agriculture). Dissert./ Göttingen Univ./ Gôttingen/ D./1983.

ESFAHANI H.S., A system-wide analysis of the impact of policy on agricultural performance in Egypt. Ph.D./ Univ. of California/ Berkeley, CA./ U.S.A./1984.

MOURSI A.al-F., Government intervention and the impact on agriculture: the case of Egypt. Ph.D./ Univ. of California/ Berkeley, CA./ U.S.A./1986.

EL BATRAN M.M., The impact of alternative policies on the food gap for strategic crops in Egypt. Ph.D./ Colorado State Univ./ Fort Collins, CO./ U.S.A./1989.

FANCHETTE S., Le Delta du Nil : densités de population et urbanisation des campagnes.Th. géo. (nouv.rég)./ Univ. Paris Vlll/ St Denis/ F./1992.

\subsubsection{Politique fiscale agricole}

EL SAID M., Les impôts fonciers en Égypte. Th.Dr.Eco./ Univ. de Dijon / Dijon / F./ 1921.

DIRAZ H.A.M., Taxation and agricultural development in the UAR. Ph.D./ Univ. of Pennsylvania/ Philadelphia, PA./ U.SA/1968.

\subsubsection{Politique des prix agricoles}

AL-KAISSOUNI A.M., Monetary policy in agricultural raw material producing countries, with special reference to Egypt. Ph.D./ London School of Economics/ London/ G.B./ 1942.

AHMED E.E.D.H., Prices and government controls in the marketing of egyptian cotton. Ph.D./ Bristol Univ./ Bristol/ G.B./1954.

EMARAH R.al-S., Potential self-sufficiency in major Egyptian crops: necessary production and price policies as estimated by an econometric model. Ph.D./ Iowa Sta. Univ. of Sc. \& Tech./ Ames, IO./ U.S.A./1982.

MOUKHTARI F.L., Government intervention, price manipulation and agricultural productivity: acomparative analysis of wheat and cotton productivity in Iran and Egypt. Ph.D./ Univ. of Delaware/ Newark, DE./ U.S.A./1983.

DETHIER J.J., The political economy of food price in Egypt. Ph.D./ Univ. of California/ Berkeley.CA./ U.S.A./1985.

\subsubsection{Politique d'aide à la production}

HILL P., Government aid to the cultivator in Egypt. M.Com./ Birmingham Univ./ Birmingham/ G.B./1933. 


\section{Sociologie et anthropologie rurales}

\section{1. Études holistes de la société rurale}

\subsubsection{Portrait sur l'Égypte rurale en général}

NAHAS Y., Situation économique et sociale du fellah égyptien. Th. Dr./ Univ. de Paris/ Paris/ 1901.

RASHIDI Z.R.G., The Egyptian village. B.A./ Leeds Univ./ Leeds/1924.

AYROUT H., Moeurs et coutumes des fellahs, études sur le milieu et la vie des paysans d'Égypte. Th. Géo/ Univ. de Lyon/ Lyon / F./1938.

REDA Kh. S., The under-privileged of Egypt; twelve million farmers. M.A./ Univ. of Wisconsin/ U.S.A./1942.

EL ABD S., The Egyptian village. M.A./ Univ. of North Carolina/ U.S.A./1946.

SELIM I., General relationship between the size of the farm and rural life with reference to the Lower Nile Vallee region and the southeastern region of the United States. MA./ Univ. of North Carolina/ U.S.A./1948.

SELIM I., Planned rural community for the Nile Vallee. Ph.D./ Univ. of North Carolina/ U.S.A7 1950.

MORCOS F.N., The Egyptian village. Ph.D./ Illinois Institut of Techn./ Chicago, IL./ U.S.A./ 1958.

ISSAC S.B., A sociological study of the egyptian countryside. Ph.D./ Wales Univ./ Aberystwyth/ G.B./1960.

EL DEEB Z., Notre image - «La sortie au jour ». Continuité des gestes, des techniques et des traditions des paysans égyptiens de la Vallée du Nil, de l'époque pharaonique à nos jours. Th. État/ Univ. de Paris I/ Paris/ F./ 1987.

\subsubsection{Approche monographiques}

ABOU ZAYD A.M., The Great Oasis: a study of the social institutions of Al Kharga, an egyptian oasis of the Western Desert. Ph.D./ Oxford University/ Oxford/ G.B./ 1957.

DREIUNG E., Marjut-Fischer im nordwesllichen Nildelta (Les pêcheurs du lac Maryut dans le nord-ouest du Delta du Nil). Dissert./ Wien Univ./ Wien/ Ö./1962.

FAKHOURY H.I., Kafr el-Helow: an Egyptian village in transition. Ph.D./ Michigan State Univ./ East Lansing, Ml./ U.S.A./1969.

BRISSAUD Ph., Les ateliers de potiers de la région de Louqsor. Th. 3ème C./ Univ. Paris V/ Paris/ F./1975.

ABOUKORAH Kh., Industrialisation et changement social. L'exemple de quatre villages de la République Arabe d'Égypte. Th. État/ Univ. de Paris V/ Paris/ F./1979.

HENEIN N.H., Un village en Haute-Égypte, Mari Girgis. Th. 3ème C./ Univ. Aix-Marseille I/ Aix-en-Provence/ F./1979.

EL ATTAR M., Les Nubiens d'Égypte : un exemple de changement social. Th. 3ème C./ Univ. de Caen/Caen/ F./1980. 


\subsubsection{Morphologie sociale} MA./ U.S.A./1956. New York, N.Y./ U.S.A./1966. Univ./ Reading/ G.B./1969. Bauwesen/ Weimar/ D./1972. 1979.

GHOSH A., Kinship in relation to economic and social organization in an egyptian village community. Ph.D./ Oxford Univ./ Oxford/ G.B./1982.

CUNO K.M., Landholding, society and economy in rural Egypt, 1740-1850: a case study of AI Daqhaliyya Province. Ph.D./ Univ. of California/ Los Angeles/ U.S.A./1985.

DREJER F.J., From «nega » (camp) to. «izba » (village): continuity and change among the Awlâd 'Ali of Egypt's western desert. Ph.D./ Northwestern Univ./ Evanston, IL./ U.S.A./1985.

HIVERNEL J., Balât, étude éthnologique d'un village égyptien de l'oasis de Dakhla. Th. 3ème C./ Univ. d'Aix-Marseille/ Aix-en-Provence/ F./1985.

\section{2. Études thématiques de la société rurale}

\subsubsection{Aménagement spatial des villages et habitat rural}

HASSID S.Y., Rural housing reconstruction in Egypt. Ph.D./ Harvard Univ./ Cambridge,

ABOU HAMADA K.M., An approch to village planning and design in the UAR. Ph.D./ Columbia Univ./ New York, N.Y./ U.S.A ./ 1963.

ZAHRAN M.M., New settlements and environmental harmony: rehousing the Nubians in Egypt. Ph.D./ Princeton Univ./ Princeton, N.J ./ U.S.A. / 1965.

KHOURI-HADDAD Y.P., Architecture and climate in rural Egypt. Ph.D./ Columbia Univ./

FAHIM H.M., The ressetlement of Egyptian Nubian: a case study in development change. Ph.D./ Univ. of California/ Berkeley, CA./ U.S.A./1968.

HEGAZI M., Rural settlement and land use planning in Faqus district of Egypt. Ph.D./ Reading

AL-ALFI M.H., Zur Industrialisierung der ägyptischen Fellahenhauses: Analyse, Nutzungsuntersuchung und Vorfertigungsmöglichkeiten (L'industrialisation de la production de la maison paysanne égyptienne: analyse, recherches concernant son utilisation et possibilités de mise en application). Dissert./ Hochschule für Archit. u.

MORCOS K.R., The impact of migration on rural and urban settlement patterns in Egypt. Ph.D./ Queen's Elizabeth Univ./ Belfast/ G.B./1975.

RADWAN T.AA, Rural settlement and land use planning in muhafazat El Oalyubiyya of the egyptian Nile Delta. Ph.D./ Wales Univ./ Aberystwyth/ G.B./1976.

2 AL-EMBABY A.I., Ländliche Bau und Siedlungsformen in den Dörfern des Aswan Gebietes, Süd Ägyptens (Constructions rurales et formes d'établissements humains dans les villages de la région d'Aswan, au sud de l'Égypte). Dissert./ Mûnchen Techn. Univ./ Mûnchen/ D./

413 AL SAYAD M.T., Entwicklungsmöglichkeiten des Siedlungsstruktur in Iàndiichen Räumen Âgyptens unter Berûcksichtigung des Fremdenverkers, dargestellt am Beispiel der Region Marsa Matruh (Possibilités de développement de la structure des établissements humains dans les espaces ruraux égyptiens, sous leur rapport avec le tourisme, d'après l'exemple de la 
région de Marsa Matruh). Dissert./ Techn. Hochschule, Fak. f. Bauwesen/ Aachen/ D./ 1979.

414 CASTEL G., Matériaux pour une étude de l'architecture rurale et désertique en Égypte. Th. 3ème C./ Univ. de Lyon II/ Lyon/ F./1979.

ELKADDI I.M., Typological production in architecture: the underlying principles in modern mass housing (Gourna, Egypt). Ph.D./ Univ. of Pennsylvania/ Philadelphia, PA./U.S.A./ 1983.

416 WEIDNER-READ B.L., Water, women, health and housing: a case study of rural reconstruction in Egypt. Ph.D./ Univ. of Utah/ Salt Lake City, UT./ U.S.A./ 1983.

417 DREJER F.J., From «nega » (camp) to «izba » (village): continuity and change among the Awlàd 'Ali of Egypt's western desert. Ph.D./ Northwestern Univ./ Evanston, IL./U.S.A./1985.

\subsubsection{Population rurale : densités, mouvement naturel, fécondité et contrôle des} naissances, urbanisation

418 FARID I.A., The introduction of perennial irrigation in Egypt and its effects on the rural economy and population problems of the country. Ph.D./ University College/ London/ G.B./ 1937.

419 AL SHAFIE M.A., Population pressures on land and the problem of capital accumulation in Egypt. Ph.D./ Univ. of Wisconsin/ Madison, Wl. / U.S.A./1951.

HAMDAN G.M., The population of the Nile Mid Delta, past and present: a study in dialectical integration in regional economy. Ph.D./ Reading Univ./ Reading/ G.B./1953.

EMBABI F.M.S., Population changes in the Nile Delta, 1927-1960. M.Litt./ Bristol Univ./ Bristol/G.B./1968.

KAKAFI L.H., Age at manage and cumulative fertility in rural Egypt. Ph.D./ Duke Univ./ Durham, N.C./U.S.A. /1983.

BAKFALOUNI T., Les effets démographiques des épidémies, des guerres et des disettes au Proche-Orient du VIle au XIXe siècle. Th. 3ème C./ EHESS/ Paris/ F./1984.

OSMAN M., Evaluation of the population and development program's impact on family planning in rural Egypt. Ph.D./ Cornell Univ./ Ithaca, N.Y./ U.S.A./1984.

AL-ESSAWY F.M., Population and food resources in Menoufiyya, Egypt. Ph.D./ Durham Univ./ Durham/ G.B./1985.

FANCHETTE S., Le Delta du Nil : densités de population et urbanisation des campagnes.Th. géo. (nouv.rég)./ Univ. Paris Vlll/ St Denis/ F./ 1992.

\subsubsection{Exode rural et migrations externes de main-d'oeuvre}

HENUFA N., Die Bevölkerungsbewegung in Âgypten und ihre Bedeutung fur die Volkswirtschaft (Les mouvements de population en Égypte et leur signification politico-économique). Dissert./ Graz Univ./ Graz/ ö./ 1968.

MORCOS K.R., The impact of migration on rural and urban settlement patterns in Egypt. Ph.D./ Queen's Elizabeth Univ./ Belfast/ G.B./1975.

SAKR M. \& LUCIA M.C., Les déplacements de population provoqués par la mise en eau du HautBarrage d'Aswan. Th. 3ème CI Univ. Paris XI Nanterre/ F./1975.

RIHAN 1., Démographie et exode rural en Égypte. Th. État/ Univ. Paris Xll/ Paris/ F./ 1981. 
SOHL CF., Egyptian migrant peasants in Irak: a case study of the settlement community in Khalsa. Ph.D./ Redford College/ London/G.B./1984.

EL-GAMMAL A., Analyse de la migration de la main-doeuvre égyptienne. Th. État/ * / * /F./ 1985.

KALLAN J.E., The assimilation of internal migrants to large cities in the Third World: a comparative study. Ph.D./ Univ. of North Carolina/ Chapel Hill, N.C./ U.S.A7 1986.

TOTH J.F., Migrant workers in the Egyptian Delta. Ph.D./ State Univ. of New York/ Binghamton, N.Y./ U.S.A./ 1987.

MOHIE ED DIN M.M., Peasant migration from an egyptian village to the oil producing countries; its causes and consequences. Ph.D./ Univ. of North Caroline/ U.S.A /1987.

\subsubsection{Structure et organisation sociale}

\subsubsection{Parenté et structures familiales}

WILLIAMS N.V., Factory employment and family relationships in an Egyptian village.

Ph.D./ The Univ. of Michigan/Ann Arbor, Ml./ U.S.A./1964.

GHOSH A., Kinship in relation to economic and social organization in an egyptian village community. Ph.D./ Oxford Univ./ Oxford/ G.B./1982.

\subsubsection{Les femmes rurales (rôles, statuts, conditions de vie)}

MEKKI S.I., A comparative study of the health of women employed in the english and egyptian cotton industries. Ph.D./ School of Hyg. \& Tropical Med./ London/ G.BV 1968.

PEGURIER J., La vie relationnelle de la femme égyptienne en milieu rural. Th. 3ème $C$./ Univ. de Paris Vil/ Paris/ F/1978.

WASSEF M., L'image de la femme à la campagne dans le cinéma égyptien des années soixante. Th. 3ème C./ EHESS/ Paris/ F./ 1982.

WEIDNER-READ B.L., Water, women, health and housing: a case study of rural reconstruction in Egypt. Ph.D./ Univ. of Utah/ Salt Lake City, UT./ U.S.A./ 1983.

BRINK J.H., The effect of education and employment on the status of rural Egyptian women. Ph.D./ Univ. of Pittsburgh/ Pittsburgh, PA./ U.S.A./1985.

JENNINGS A.M., Power and inluence: women's associations in an Egyptian Nubian village. Ph.D./ Univ. of California/ Riverside, CA./ U.S.A./1985.

ABAZA M., Women between economic liberalization and social deprivation: a case study in rural Egypt. M.Arts/ Durham Univ./ Durham/ G.B7 1986.

AL MOGHAZI D.A., Women's role in rural Egypt: a case study of an egyptian village (al Khelala, Daqahliyya. Ph.D./ Manchester Univ./ Manchester/ G.B./1987.

\subsubsection{Santé et services sociaux}

AHMED A.F., The rural social centers in Egypt. M.A./ Univ. of Tennessee/ U.S.A./ 1950.

MEKKI S.I., A comparative study of the health of women employed in the english and egyptian cotton industries. Ph.D./ School of Hyg. \& Tropical Med./ London/ G.B./1968. 

Chapel Hill, N.C./ U.S.A./ 1952. 1973.

ABDELGABER T., Allocation spatiale des ressources du système de santé égyptien. Th. 3ème $C$./ Univ. d'Aix-Marseille II/ Aix-en-Provence/ F./1982.

WEIDNER-READ B.L., Water, women, health and housing: a case study of rural reconstruction in Egypt. Ph.D./ Univ. of Utah/ Sail Lake City, UT./ U.S.A./ 1983.

AFIFI Z.E.M., The determinants of growth of infants in an Egyptian village. Ph.D./ Harvard Univ./ Cambridge, MA./ U.S.A./1984.

RICE K.S., The allocation, dietary intake and productivity in a schistosomiasis stressed Egyptian village. Ph.D./ Univ. of Utah/ Salt Lake City, UT./ U.S.A./1985.

WRIGHT Ch.E., Feasibility of correlating incidence of diarrhea with characteristics of rural Egyptian households by means of an environmental survey. Ph.D./ Health Sc.Center, Univ. of Texas/ Houston, TX./ U.S.A./1985.

RABIE M.K., Rural service provision and key settlement policy in Egypt's village clusters. Ph.D./ Manchester Univ./ Manchester/ G.B./1985.

SULLIVAN P.S., A study of illness and reservoirs associated with "Giardia lamblia » in rural Egypt. Ph.D./ Health Sc.Center, Univ. of Texas/ Houston, TX./ U.S.A./ 1986. BELASCO D.B., Adoption of community water systems: an area study in three villages in Muhäfaza Kafr ash-Shaykh. Ph.D./ Univ. of Denver/ Denver, CO./ U.S.A./ 1991.

\subsubsection{Développement communautaire rural}

AHMED A.F., A proposed experiment in community change by the people of a selected Egyptian village. Ph.D./ Vanderbilt Univ./ Nashville, TE./ U.S.A./1952.

SELIM I.M., Planned rural community for the Nile Valley. Ph.D./ Univ. of North Carolina/

GADALLA M.S.S., Land reform in relation to social development of the farm population in Egypt. Ph.D./ Univ. of Missouri/ Columbia, MO./ U.S.A./ 1960.

AL SHINNAWY M.A., Communauty development and local government in the developing nations: a study based on the experience of the UAR, India and Pakistan. Ph.D./ New York Univ./ New York, N.Y./ U.S.A./ 1964.

FAHIM H.M., The ressetlement of Egyptian Nubian: a case study in development change. Ph.D./ Univ. of California/ Berkeley, CA./ U.S.A./ 1968.

AL ZOGHBIY S.M., Community development as a function of the gap between social classes: a case study of the UAR. Ph.D./ Univ. of Wisconsin/ Madison, Wl./ U.S. A./ 1970.

NOURY M.M., The impact of the individual and rural community variables on the adoption of new farm practices in rural Egypt. Ph.D./ Iowa State Univ. of Sc.\& Tech./Ames, IO./ U.S.A./

\subsubsection{Administration et pouvoirs locaux}

AL SHINNAWY M.A., Communauty development and local government in the developing nations: a study based on the experience of the UAR, India and Pakistan. Ph.D./ New York Univ./ New York, N.Y./ U.S.A./1964.

MAYFIELD J.B., The institutions and politics of rural Egypt: their implication for political legitimization. Ph.D./ Univ. of Texas/ Austin, TX./ U.S.A./1968. 
AL ASSAM M.H.M., A comparative analysis of local administration in Egypt and Sudan. Ph.D./ Wales (UWIST)/ G.B./ 1977.

OMAR I.A.A., Participation and efficency in local government reform (Egypt and Nigeria). Ph.D./ Birmingham Univ./ Birmingham/ G.B./1977.

\subsubsection{Paysannerie et politique}

HEGAZI A.M., Bauembewegungen in Ägypten : drei Fallstudien zur Analyse der Beteiligung der ägyptischen Bauern an den nationalen und sozialen Bewegungen (Les mouvements paysans en Égypte : trois études de cas pour l'analyse de la participation des paysans égyptiens aux mouvements sociaux et nationaux). Dissert./ Bielefeld Univ./ Bielefeld/ D./1983.

BROWN N.J., Peasants against the state: the political activity of the Egyptian peasantry, 1882-1952. Ph.D./ Princeton Univ./ Princeton, N.J./ U.S.A./1987.

\subsubsection{Culture et représentations}

\subsubsection{1. Éducation, socialisation, enseignement et formation}

AMMAR H.M., A study of growing up in an egyptian village community (Silwa, Province of Aswan. Ph.D./ Institute of Education/ London/ G.B./1952.

METAWEH I.E., Improvement of rural teacher education in Egypt. Ph.D./ Univ. of Minnesota/ Minneapolis, MIN./ USA./1954.

AL MARSAFY M.A., The training of primary school teachers for egyptian rural areas. Ph.D./ Wales Univ./ Cardiff/ G.B./1979.

SAMI M.M., A comparative study of basic athletic skills among rural and urban area pupils in egyptian primary school. M.Educ./ Wales Univ./ Cardiff/ G.B./1979.

473 AL HAYDARY A.R., Der Einfluss der làndiichen Genossenschaftstypen in Âgypten auf die Bildung und Ausbildung ihrer Mitglieder (L'influence des types de coopératives rurales en Égypte sur la culture et la formation de leurs membres). Dissert./ Giessen Univ./ Giessen/ D./1983.

\subsubsection{Communication et médias}

ARAFA M.MA, Communication structure and social structure in an Egyptian village. Ph.D./ Univ. of Virginia/ Charlottesville, VA./ U.S.A./1986.

ELGINDI I.A., Rural radio in Egypt: its promise and performance. Ph.D./ Florida State Univ./ Tallahassee, FL./ U.S.A./1986.

\subsubsection{Linguistique et dialectologie}

DOSS M., Le dialecte sa'idi de la région de Menya. Th. 3ème $\mathrm{Cl}$ Univ. de Paris III/ Paris/F./ 1981.

\subsubsection{Religion}

GAFFNEY P.D., "Shaykh", "khutba ", and " masjid »: the role of the local Islamic preacher in Upper Egypt. Ph.D./ Univ. of Chicago/ Chicago, IL./ U.S.A./1982. 


\section{NOTES}

1. Cf. IRETON François, « Agriculture et société rurale égyptiennes : essai de bibliographie (1980 1er septembre 1986) (1ère partie)» Bulletin du CEDEJ, 19, 1er sem.1986, pp. 213-260. Cette première partie comprenait, d'une part, des articles «de fond " paru dans la presse égyptienne hebdomadaire - essentiellement al-Ahrâm al-iqtisâdi, - et d'autre part des articles parus en langues arabe et européennes dans diverses revues scientifiques (des compléments à cette bibliographie pour la même période de référence ainsi qu'une actualisation pour les années 1987-1993 seront publiés dans un prochain numéro d'Égypte-Monde Arabe). La deuxième partie IRETON François, « Agriculture et société rurale égyptienne : essai de bibliographie (2e partie) » Bulletin du CEDEJ, 21, 1er sem.1987, pp. 221-246 - concernait la « littérature grise " (rapports, working papers) parue de 1980 à 1987 (des compléments et une actualisation 1987-1993 paraîtront également ultérieurement).

2. Ont été ajoutées (pour des raisons données en notes 4 et 5 ) des thèses soutenues en Autriche

(Ô) et en Suisse (S), ainsi qu'au Canada (C).

3. Dans ce dernier cas, une traduction du titre allemand est donnée en langue française (insérée entre parenthèses après ce dernier).

4. Pour les États-Unis: (a) Dissertation abstracts, Ann Arbor, Mich, (annuel) (série consultée jusqu'au volume de 1991); (b) University Microfilms International, Research on Economics, a catalogue of Doctoral Dissertations, 1989-1991, Ann Harbor, Mich., UMI's Dissertation Information Service, August 1991. Pour la Grande-Bretagne: (a) thèses soutenues jusqu'en 1950: R. R. BILBOUL and F. L. KENT (eds.), Retrospective index to theses of Great Britain and Ireland 1716-1950, London, 1975 ; (b) depuis 1950 : ASLIB, Index to theses accepted for higher degrees by the universities of Great Britain and Ireland and the Council for National Academic Awards, London (annuel) ; (aucune référence provenant d'Irlande n'a été trouvée dans ces publications; série consultée jusqu'au volume de 1991). Pour l'Allemagne, Jahresverzeichnis der deutschen Hochschulschriften (Catalogue annuel des thèses universitaires) (série consultée jusqu'au volume de 1989). Pour la France, les «Catalogues des thèses de doctorat soutenues dans les universités françaises » ne comportant pas d'index des noms géographiques cités dans les titres, on a dû renoncer à un dépouillement systématique des thèses, classées annuellement dans ces catalogues par Université et discipline. L'on s'est contenté de dépouiller le fichier «matières" des thèses de droit et de sciences économiques de la Bibliothèque Cujas (Paris), qui contient les références de la totalité des thèses soutenues depuis la fin du XIXe siècle à Paris et en province dans ces disciplines; ces dernières bien que par définition aucun test n'ait pu en être fait pour les années antérieures à 1973 (première année prise en compte par le répertoire «THESAM ", cf. note 5) - regroupent une très forte proportion des thèses susceptibles d'être concernées par les thèmes de cette bibliographie.

5. Pour les États-Unis : (a) G. D. SELIM (ed.), American Doctoral Dissertations on the Arab World, 1883-1974 (second edition), Washington, Library of Congress, 1976 ; (b) idem, first supplement (1975-1981), Library of Congress, 1983 ; (c) idem, second supplement (August 1981 - December 1987), Library of Congress, 1989. Ces répertoires donnent la liste des PhD soutenus aux États-Unis et au Canada (aucune référence concernant les thèmes pris en compte ici ne provient de ce dernier pays, sauf une, datant de 1991, trouvée ailleurs). Pour la Grande Bretagne : P. SLUGETT (ed.), Theses on Islam, the Middle East and North-West Africa 1880-1978, accepted by universities in the United Kingdom and Ireland, Mansell Publishing Limited, London, 1983. D'autre part, les références de quelques thèses de master et mémoires de bachelor, des USA et de GB, datant d'avant 1955, proviennent de Lyman H. COULT, An Annotated Research Bibliography of Studies in Arabic, English and French of the Fellah of the Egyptian Nile (1798-1955), The University of Miami Press, Coral Gables, Florida, 1958. Pour l'Allemagne, K. SCHWARTZ, Der vordere Orient in den Hochschulschriften 
Deutschlands, Österreichs und der Schweiz; eine Bibliographie von Dissertationen und Habilitationsschriften, 1885-1978 (le Moyen-Orient dans les écrits universitaires d'Allemagne, d'Autriche et de Suisse ; une bibliographie des thèses de doctorat et d'habilitation, 1885-1978) (Islamkundliche Materialen, Band 5), Freiburg in Brisgau, Klaus Schwarz Verlag, 1980 (ce répertoire contient donc aussi les thèses soutenues en Autriche et en Suisse). Pour la France : J. QUILES, Le monde arabe et musulman au miroir de l'Université française, Répertoire des thèses en Sciences de l'Homme et de la Société (1973-1987), THESAM III, Machrek, Travaux et Documents de l'IREMAM $\mathrm{n}^{\circ}$ 12, Aix-en-Provence, 1991. Par ailleurs, quelques références à des mémoires de DEA et DESS ont été trouvées dans la bibliographie de T. RUF, Histoire contemporaine de l'agriculture égyptienne, Paris, ORSTOM, collection «Études et thèses ", 1988.

6. Quelques thèses du corpus, pratiquant la comparaison internationale sur un point précis, concernent - toujours d'après leur intitulé - l'Égypte et d'autres États du Moyen-Orient ou d'Asie (dont certaines des régions qui la composent - en particulier les vallées et deltas du Gange et de l'Indus ainsi que l'Ile de Java - présentent, du point de vue de leurs cadres physiques et des caractéristiques socio-économiques de leur agriculture et de leur peuplement, bien des points communs avec l'Égypte rurale, plus que n'en comportent les autres régions du Monde arabe, plaines irakiennes du Tigre et de l'Euphrate mises à part). On a aussi intégré à cette bibliographie certaines thèses portant sur différents aspects des agricultures du Moyen-Orient et dont seuls les index géographiques des répertoires consultés permettent de savoir qu'elles concernent aussi l'Égypte.

7. $\mathrm{Vu}$ les répertoires qu'il a été possible de consulter (cf. notes 4 et 5), le corpus est quasi exhaustif pour l'ensemble des disciplines, des «origines » à 1991, pour les États-Unis et la Grande-Bretagne (et, bien que ne comportant qu'une seule référence, pour le Canada et l'Irlande). Il en est de même pour l'Allemagne (ou les « deux » Allemagnes) jusqu'en 1989 et pour l'Autriche et la Suisse jusqu'en 1978. Paradoxalement, c'est pour la France que la quasiexhaustivité n'est assurée dans toutes les disciplines que de 1973 à 1987 ; elle ne l'est, s'agissant des thèses soutenues avant 1973, qu'en matière de droit et de sciences économiques. Cependant, un nombre non négligeable de titres de thèses soutenues après ces terminus ad quem a pu être joint au corpus, sur la base de la connaissance personnelle (ou par ouï-dire) des auteurs et/ou de leur travail.

8. Si la quasi-exhaustivité avait pu être atteinte en ce qui concerne les références de thèses soutenues en France, le nombre de ces dernières dépasserait sans doute un peu celui des travaux soutenus en Allemagne.

9. $D$ 'après les répertoires cités en note 5 , $a$.

10. L'on peut objecter que cette comparaison est aventureuse, le rythme de progression des thèses soutenues dans le domaine des sciences sociales « appliquées » au Monde arabo-musulman n'étant pas nécessairement le même aux USA que dans les autres pays pris en compte ici; concernant les seules thèses passées aux USA sur les thèmes touchant à l'Égypte rurale, les résultats pour les deux périodes de référence sont les suivants : 0,6 thèse/an contre 4 thèses/an (effectifs : 53 et 28), soit une multiplication par 6,6 (chiffre peu éloigné de 5,5 et qui devient encore plus faible si l'on tient compte du fait qu'aucune thèse n'a été soutenue avant 1940 aux USA sur ces thèmes: on a alors 1,5 thèse/an pour 1940-74 et une multiplication par 2,7 seulement).

11. Si les effectifs d'étudiants venus des pays arabes sont nettement plus importants aux ÉtatsUnis que dans les autres pays pris en compte, les taux de croissance de ces effectifs sont de même ordre.

12. La méthode employée ici est des plus fruste; elle consiste à faire l'hypothèse, pour un pays de soutenance donné, que tous les auteurs travaillant sur l'Égypte et ayant un anthroponyme arabe sont d'origine égyptienne et que les autres auteurs sont des nationaux du pays de soutenance (les résultat obtenus ne sont donc qu'approximatifs, surtout dans le cas des thèses - au demeurant 
peu nombreuses - portant également sur d'autres pays que l'Égypte, la probabilité étant grande dans ce cas que l'auteur soit originaire de l'un des autres pays étudiés, arabe ou non ; par ailleurs, c'est l'origine nationale qui est ici prise en compte et non la nationalité actuelle, certains étudiants d'origine égyptienne pouvant avoir pris la nationalité du pays de soutenance ; enfin, rien n'implique nécessairement que tout doctorant à anthroponyme non arabe soit un national du pays de soutenance).

13. Notons qu'un test de "khi deux» ne pouvait être appliqué en toute rigueur aux tableaux croisés ainsi formés, vu l'existence de cases comportant des effectifs inférieurs à 5 (appliqué néanmoins, il indique l'existence de liaisons significatives entre ces indicateurs, à un seuil de probabilité de 0,99).

14. Seule case apparemment « remarquable» du tableau croisant ces deux données (et que l'on ne reproduit pas ici), celle qui se trouve au point de rencontre de la socio-anthropologie rurale et de l'origine "américaine » : sur 35 thèses soutenues par des étudiants de cette origine, 14 (soit $40 \%$ relèvent de cette discipline qui ne compte que pour $22 \%$ de la totalité des 339 travaux répertoriés. Y aurait-il un "tropisme» particulier des étudiants "ruralistes" américains travaillant sur l'Égypte pour l'anthropologie? Si l'on tient compte du fait que $35 \%$ des thèses soutenues aux USA sur l'Égypte agricole et/ou rurale le sont dans cette discipline, la réponse est pratiquement négative, ce que confirme l'observation selon laquelle la proportion d'américains, parmi les auteurs de thèses de socio-anthropologie rurale portant sur l'Égypte, est pratiquement la même que celle de thésards américains dans l'ensemble des auteurs de PhD soutenus aux USA sur le secteur rural et/ou agricole égyptien (respectivement $37 \%$ et $33 \%$ ).

15. On ne peut résister ici au plaisir d'une parenthèse à propos d'un cas tout à fait atypique (et réjouissant $\mathrm{I}$ ), non seulement de "réécriture » de thèse et d'utilisation de ses matériaux, mais encore d'itinéraire de son auteur et de démarche. Il s'agit de la recherche qu'entreprit en 1980, dans le cadre de la préparation d'un $\mathrm{PhD}$ en anthropologie sociale à l'Université d'Oxford, un anthropologue indien d'origine bengalie, devenu depuis romancier connu, Amitav (ou Amitabh) Ghosh, dans un petit village du Delta du Nil, dit Lataïfa, situé au sud-est d'Alexandrie. Ce PhD fut soutenu en 1982 sous le titre fort classique de Kinship in relation to economic and social organization in an Egyptian village community, mais ses «matériaux" ont donné lieu, moins classiquement, à une réexploitation dans un roman, à la foi historique et "contemporanéiste", intitulé In an antique / and (Ravi Dayal, New Delhi, 1992 (383 p.) ; cf. compte rendu de Preeti Singh, dans Al-Ahram weekly au 4-10 février 1993), roman "structurellement comparatiste", à deux voix, deux temps et plusieurs lieux, ceux d'un marchand juif tunisien voyageant vers l'Inde en 1130, via l'Égypte, et ceux d'un anthropologue indien sillonant l'Égypte rurale dans les années 80 de ce siècle, dont le regard est aiguisé par les profondes ressemblances et fortes dissemblances qui lient et individualisent ces deux terres de fleuve, de Delta, de très vieille culture, d'acculturation intense, de densité extrême et de "jardinage » que sont le pays qui accueille le «doctor hindi » et le Bengale natal de ce dernier. Il était déjà question de l'Égypte dans An infidel in Egypt, une oeuvre précédente du même auteur, connu maintenant en France pour son roman Les feux du Bengale (Seuil, 1990 et id., coll. " Points, Roman», 1992), traduction de The circle of Reason (Hamisch Hamilton, Londres, 1986), relevant d'une veine souvent proche de celle du Garcia Marquez de Cien anos de soledad ou du Yachar Kemal de Inje Memed. A. Ghosh est par ailleurs l'auteur d'un article intéressant: "The relation of envy in an egyptian village" Ethnology, vol. 22, $\mathrm{n}^{\circ} 3$ (pp. 211-224).

16. A noter que certaines thèses, en particulier celles soutenues aux États-Unis, font aussi l'objet de publication fragmentaire, en plusieurs articles dispersés entre des revues scientifiques différentes.

17. Les thèses soutenues en France viennent au dernier rang pour ce qui est de leur taux de publication, ceci si l'on met à part les thèses de droit et sciences économiques dont, jusque dans les années quarante, l'édition était obligatoire.

Égypte/Monde arabe, 12-13 | 1993 
18. Alors qu'une enquête sur les thèses soutenues dans les autres pays européens pose de nombreux problèmes, matériels et linguistiques (Italie, Belgique et Espagne mises à part), l'on se propose de fournir, dans une prochaine livraison d'Égypte-Monde Arabe, une bibliographie des thèses de magister et de doctorat soutenues dans les différentes universités d'Égypte sur l'agriculture et la société rurale égyptiennes.

INDEX

Mots-clés : bibliographie thèses en science sociale, secteur agricole, société rurale 